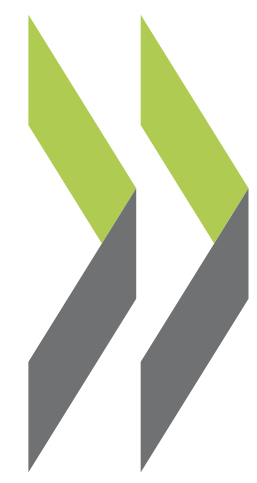

OECD Economics Department Working Papers No. 614

Enhancing the Globalisation

Randall S. Jones,

of Korea

Taesik Yoon 
Organisation de Coopération et de Développement Économiques

Organisation for Economic Co-operation and Development

ECONOMICS DEPARTMENT

English - Or. English

ENHANCING THE GLOBALISATION OF KOREA

ECONOMICS DEPARTMENT WORKING PAPERS No. 614

By Randall S. Jones and Taesik Yoon

All OECD Economics Department Working Papers are available on the OECD Internet website at www.oecd.org/eco/working_papers

JT03245712

Document complet disponible sur OLIS dans son format d'origine Complete document available on OLIS in its original format 


\section{ABSTRACT/RÉSUMÉ}

\section{Enhancing the globalisation of Korea}

Globalisation through foreign direct investment (FDI), international trade and international movements of labour is a key force driving economic growth. Although Korea has become more integrated in the world economy over the past decade, it still ranks low in terms of import penetration, the stock of inward FDI relative to GDP and foreign workers as a share of the labour force. A number of policy reforms would help Korea make greater use of goods, services, capital and human resources from abroad: $i$ ) reducing barriers to FDI, including foreign ownership limits in some sectors; ii) focusing on attracting FDI by improving the business and living environment rather than through special zone schemes; iii) reducing import barriers, particularly in agriculture, through multilateral trade negotiations and WTO-consistent regional trade agreements; iv) relaxing product market regulations, notably in services; and v) easing controls on and facilitating the inflow of both low and high-skilled workers.

This Working Paper relates to the 2007 OECD Economic Survey of Korea (www.oecd.org/eco/surveys/korea).

JEL classification: F1, F21, F22, F23.

Keywords: Korea; globalisation; foreign direct investment (FDI); service sector; mergers and acquisitions; Free Economic Zones; international trade; import penetration; trade liberalisation; free trade agreements; agricultural trade; immigration; foreign workers.

$$
* * * * * * *
$$

\section{Renforcer la mondialisation de l'économie Coréenne}

La mondialisation, par le biais de l'investissement direct étranger (IDE), des échanges internationaux et de la circulation internationale de la main-d'œuvre, est un facteur essentiel de croissance économique. Même si la Corée s'est intégrée davantage dans l'économie mondiale au cours de la décennie passée, elle est encore à la traîne du point de vue de la pénétration des importations, du stock d'IDE par rapport au PIB et de la proportion de travailleurs étrangers dans la population active. Un certain nombre de réformes aideraient la Corée à tirer meilleur parti des biens, des services, des capitaux et des ressources humaines d'origine étrangère : i) la réduction des obstacles à l'IDE, liés notamment au plafonnement des participations étrangères dans certains secteurs; ii) une stratégie visant à attirer l'IDE, axée sur l'amélioration des conditions d'activité et de vie offertes aux investisseurs étrangers et non sur des systèmes de zones spéciales; iii) la réduction des obstacles à l'importation, en particulier dans l'agriculture, par le biais de négociations commerciales multilatérales et d'accords commerciaux régionaux conformes aux règles de l'OMC ; iv) un assouplissement de la réglementation des marchés de produits, notamment dans les services; et $v$ ) un assouplissement des contrôles limitant l'entrée de travailleurs aussi bien peu qualifiés que hautement qualifiés et la facilitation de l'accès de ces catégories.

Ce Document de travail se rapporte à l'Étude économique de l'OCDE de Corée, 2007 (www.oecd.org/eco/etudes/corée).

Classification JEL : F1, F21, F22, F23.

Mots clés: Corée; mondialisation; investissement direct étranger (IDE); secteur des services; fusions et acquisitions; Zones franches; échanges internationaux; pénétration des importations; libéralisation des échanges; accords libre-échange; commerce agricole; immigration.

\section{Copyright OECD 2008}

Application for permission to reproduce or translate all, or part of, this material should be made to: Head of Publications Service, OECD, 2 rue André-Pascal, 75775 Paris Cedex 16, France. 


\section{TABLE OF CONTENTS}

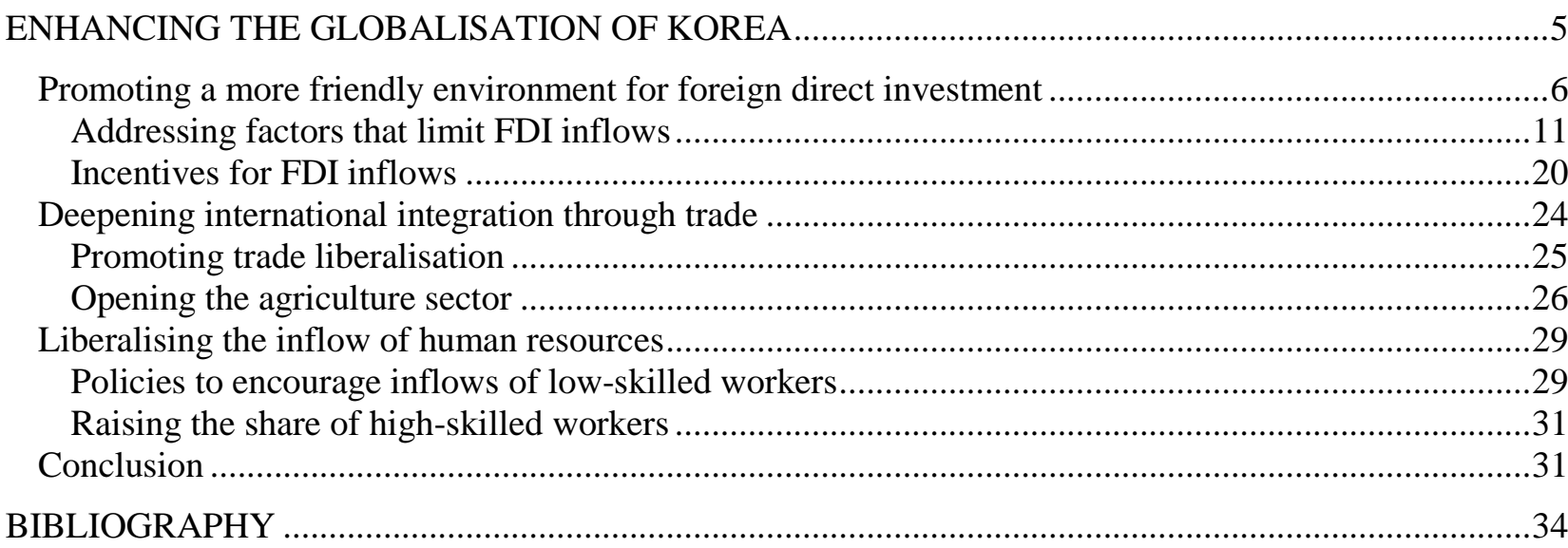

\section{Tables}

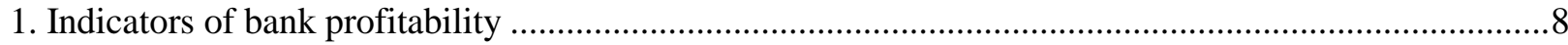

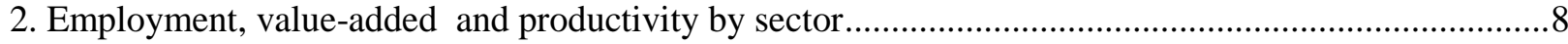

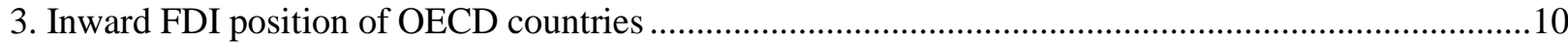

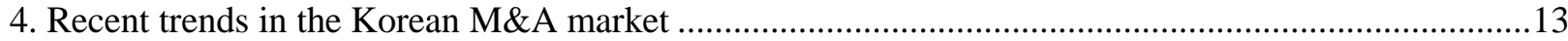

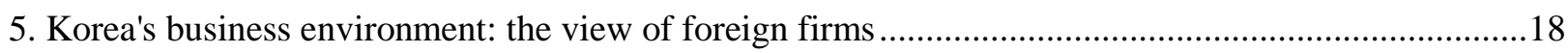

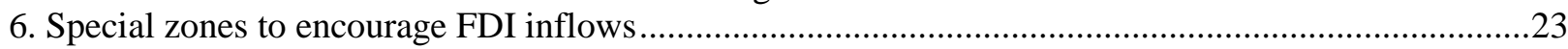

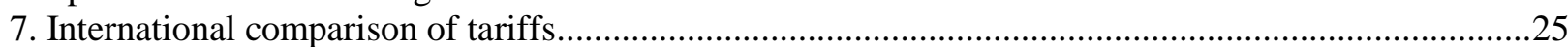

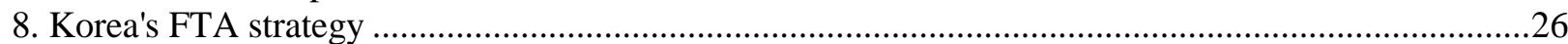

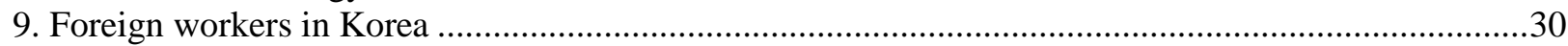

\section{Figures}

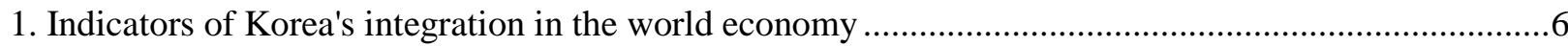

2. Share of the service sector in the stock of inward FDI in OECD countries..........................................

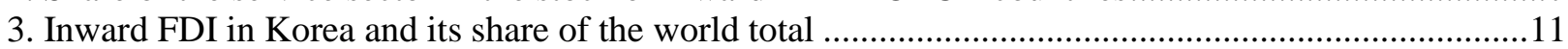

4. Product market regulation in 2003

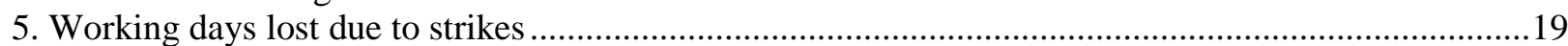

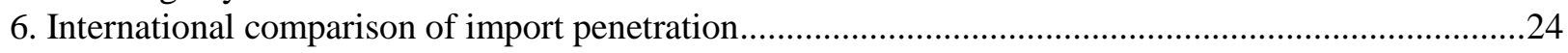

7. An international comparison of agricultural support during 2003-05 .............................................28 


\section{ECO/WKP(2008)22}

\section{Boxes}

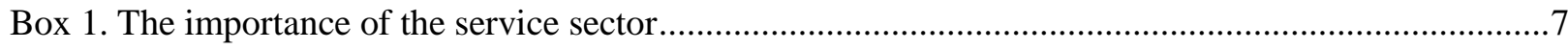

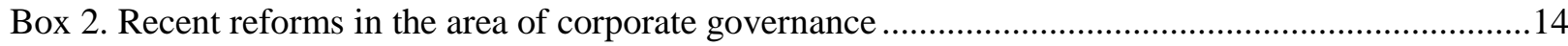

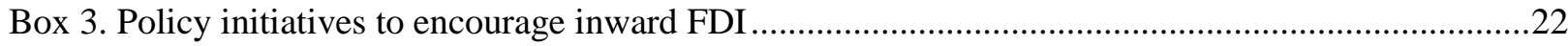

Box 4. Summary of recommendations to increase the integration of Korea in the world economy ..........32 
ECO/WKP(2008)22

\title{
ENHANCING THE GLOBALISATION OF KOREA
}

\author{
Randall S. Jones and Taesik Yoon ${ }^{1}$
}

1. The benefits of integration in the world economy are demonstrated by both economic theory and history (OECD, 2005a). Korea is one of the countries that has benefited most from increased globalisation during the past decade through freer international flows of capital, goods and services. Indeed, foreign capital played a key role in the restructuring of its financial and corporate sectors in the wake of the 1997 crisis. Foreign ownership of listed companies increased from $15 \%$ in 1997 to a peak of $42 \%$ in 2004, with foreign investors holding more than $50 \%$ of a number of leading companies, ${ }^{2}$ as a result of the liberalisation of capital inflows and wide-ranging reforms in the corporate and financial sectors. Meanwhile, exports have doubled from 29\% of GDP in 1997 to 58\% in 2006, with net exports accounting for almost half of output growth since 1997.

2. Despite increased openness, Korea's level of integration with the world economy is still low in terms of import penetration, the stock of inward foreign direct investment (FDI) and the share of foreign workers (Figure 1). Furthermore, FDI inflows declined in 2005-06, while foreign ownership of listed companies fell to $37 \%$ by the end of 2006 . At the same time, a significant segment of the Korean population questions the benefits of foreign investment and the broad-based free trade agreement recently negotiated with the United States. Addressing these issues goes beyond trade and investment liberalisation to include structural reforms, such as regulatory changes in product markets and the introduction of market principles in agriculture and social services. A new momentum for reform is now needed to further improve Korea's ability to take full advantage of globalisation. This paper discusses how the Korean economy can benefit more fully from globalisation by increasing its openness to FDI, trade and human resources from abroad, thereby accelerating productivity gains and output growth. Policy recommendations are summarised in Box 4. In addition to the recommendations in this paper, options for how to proceed are set out in the OECD report, Korea: Progress in Implementing Regulatory Reform (OECD, 2007a), particularly in its chapter on market openness.

1. Randall S. Jones is head of the Japan/Korea Desk in the Economics Department of the OECD and Taesik Yoon was an economist on that desk. This paper is based largely on material from the OECD Economic Survey of Korea published in June 2007 under the authority of the Economic and Development Review Committee (EDRC). The authors would like to thank Andrew Dean, Val Koromzay, Willi Leibfritz and Tadashi Yokoyama for valuable comments on earlier drafts. Special thanks go to Lutécia Daniel for technical assistance and to Nadine Dufour and Therese Walsh for technical preparation.

2. It is not certain to what extent increased portfolio investment has translated into increased management rights. According to a survey by the IMD, Korea ranked 37th among 60 countries in both 2001 and 2005 on the ease with which foreigners can secure management rights. 
Figure 1. Indicators of Korea's integration in the world economy

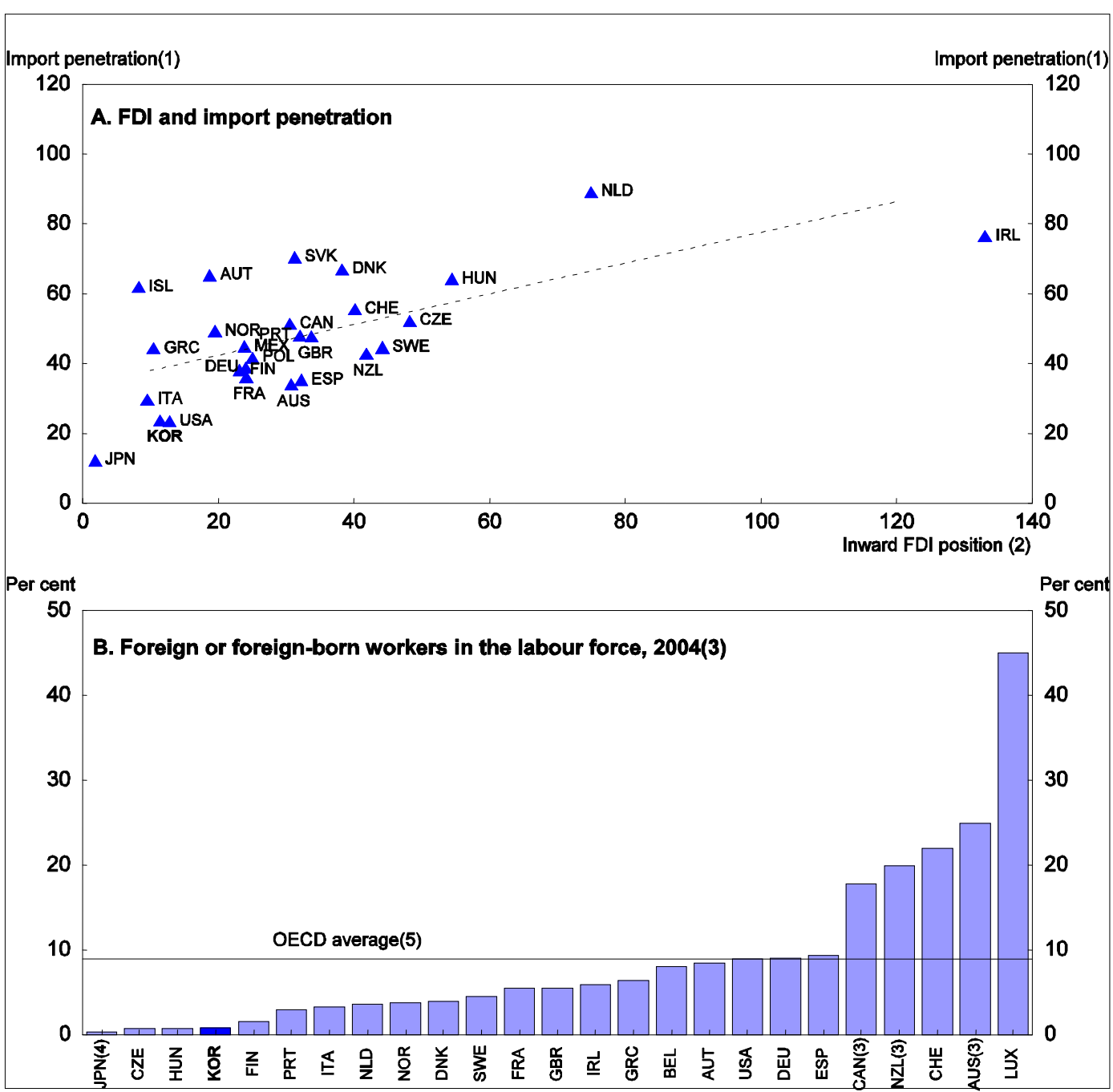

1. Imports of manufactures as per cent of domestic demand in 2003.

2. $\quad$ Stock of inward FDI as per cent of GDP in 2002.

3. Data for Australia, Canada and New Zealand (data refer to 2003) are for the foreign-born labour force. The data source is the Labour Force Survey or census in all countries except Japan and Korea, where the source is work permits.

4. $\quad$ Foreign residents with permission for employment. Excludes permanent and long-term residents, whose labour activity is not restricted.

5. Unweighted average of the 25 countries shown in this figure.

Source: OECD (2005c), Economic Globalisation Indicators; OECD (2006b), International Migration Outlook: SOPEMI 2006 Edition; and Ministry of Justice.

\section{Promoting a more friendly environment for foreign direct investment}

3. The economic benefits of FDI result from positive spill-overs from the presence of foreign firms that: i) trigger transfers of technology; ii) facilitate the restructuring of firms; iii) promote international trade; $i v$ ) strengthen competition; and $v$ ) support human capital formation. The $\$ 46.5$ billion of FDI inflows into Korea between 1998 and 2005 were more than double the amount received during the previous 35 years, and much larger than the $\$ 10$ billion received between 1991 and 1997. As a result, the stock of inward FDI rose from 2\% of GDP in 1990 to $8 \%$ in 2005, according to UNCTAD (2006). 
4. While the global investment boom during the second half of the 1990s explains some of the increase, a number of factors encouraged the surge in FDI flows to Korea. First, the extensive restructuring in the financial and corporate sectors in the wake of the crisis created a large market for cross-border M\&As. More than half of the 30 largest business groups in 1998 either went bankrupt or entered workout programmes and the number of financial institutions has fallen by $40 \%$ since 1997 . Many of the rest have survived thanks to links with foreign investors. Second, the government removed many restrictions on FDI while making vigorous efforts to attract foreign investors (see below). Third, a significant decline in stock and land prices made investment more attractive for foreign investors. Increased FDI inflows played a pivotal role in Korea's strong recovery following the 1997 crisis by providing significant capital, technology and management skills. Foreign affiliates in Korea accounted for almost a quarter of the increase in manufacturing turnover between 1997 and 2003 and their labour productivity in the manufacturing sector is estimated to be $25 \%$ higher than in domestic firms (MOCIE, 2005). However, the role of foreign-affiliated firms in the service sector has been less important (see Box 1).

\section{Box 1. The importance of the service sector}

The share of the service sector in Korea's inward FDI stock was one of the lowest in the OECD area at $44 \%$ in 2002 (Figure 2), reflecting a relatively high level of restrictions on foreign ownership and product market regulations in the service industry (see below). As a result, foreign affiliates accounted for only $8 \%$ of service sector turnover and $4 \%$ of employment in 2004 (MOCIE, 2005), compared to OECD averages of $19 \%$ and $10 \%$, respectively (OECD, 2005c). However, the service sector has accounted for about half of FDI inflows since 1997, reflecting the restructuring of the financial sector in the wake of the crisis and policies intended to develop service industries. In particular, the 2004 plan to make Korea a financial hub for Northeast Asia demonstrates the government's commitment to develop the financial industry.

Figure 2. Share of the service sector in the stock of inward FDI in OECD countries In $2002^{1}$

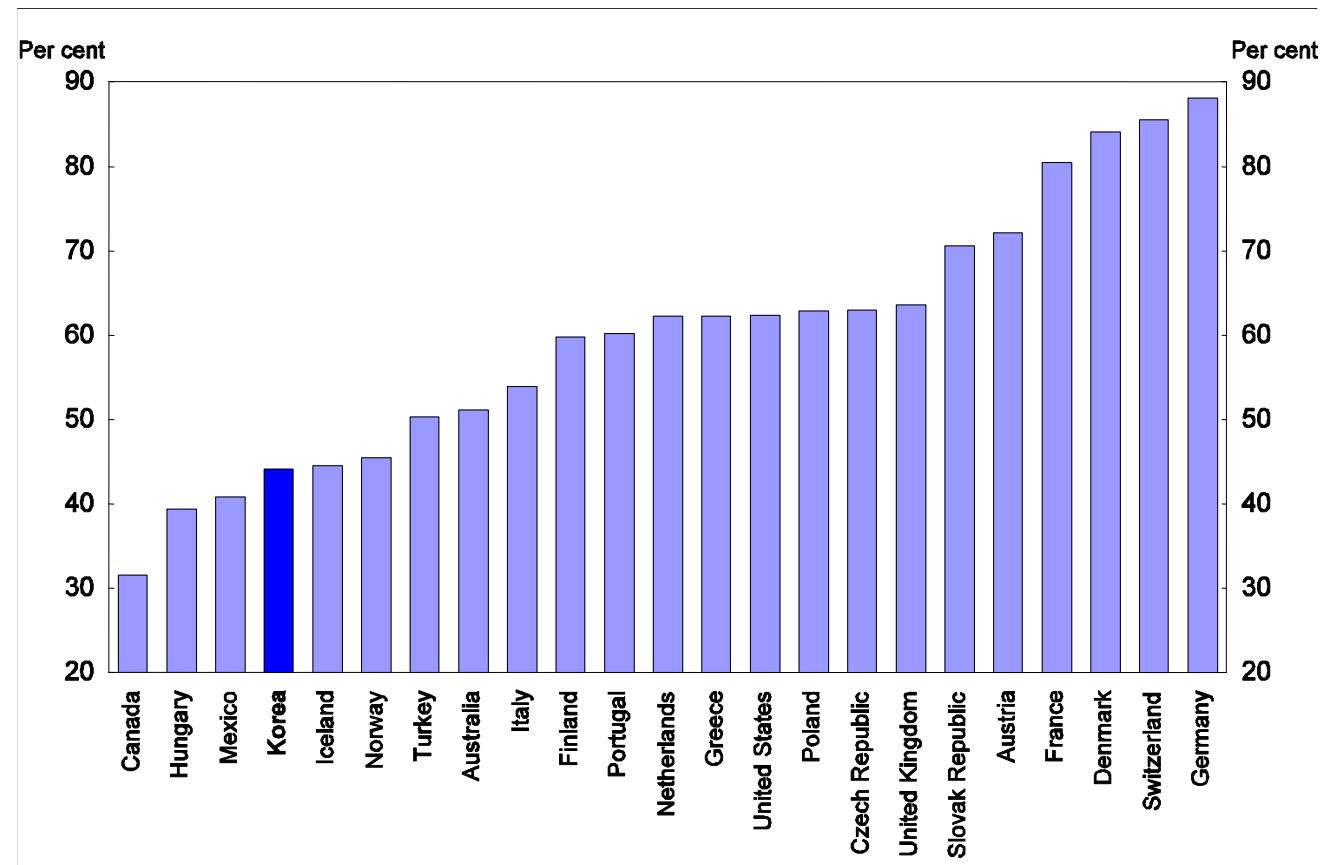

1. The breakdown is not available for Belgium, Ireland, Japan, Luxembourg, New Zealand, Spain and Sweden. 2000 for Mexico.

Source: OECD (2005c), Economic Globalisation Indicators, OECD, Paris. 
The potential gains from FDI in services is illustrated by the banking sector, which has received considerable foreign investment in recent years. ${ }^{1}$ After-tax profits increased from 3.4 trillion won in 2001 to a record high of 8.6 trillion won in 2005, while the return on asset ratio improved from $0.8 \%$ to $1.3 \%$ during the same period (Table 1). Meanwhile, loans classified as substandard or below fell to a record low of $1.3 \%$ in 2005 . The privatisation of banks re-capitalised using public funds resulted in a sharp expansion of foreign ownership in the banking sector from $16 \%$ in 1997 to $64 \%$ in 2004 . Currently, foreign investors own more than $50 \%$ of nine of the 14 commercial banks. Although much of the improved performance of the banking sector was a result of extensive government-financed restructuring after the crisis and the stronger economy, the foreign presence has greatly contributed to improving the productivity of individual institutions by promoting competition, introducing advanced know-how and practices, and strengthening risk management in lending (Kim, 2005).

Table 1. Indicators of bank profitability

Nation-wide banks, in trillion won

\begin{tabular}{|c|c|c|c|c|c|c|}
\hline & 1998 & 2001 & 2002 & 2003 & 2004 & 2005 \\
\hline \multicolumn{7}{|l|}{ Before-tax profits } \\
\hline Net profits & -3.2 & 9.0 & 9.0 & 10.7 & 12.8 & 13.5 \\
\hline Net profits minus loan loss provisions & -10.1 & 3.6 & 3.7 & 0.3 & 6.0 & 10.1 \\
\hline After-tax profits & -10.1 & 3.4 & 2.9 & 0.2 & 5.9 & 8.6 \\
\hline Return on equity (per cent) & -48.6 & 16.3 & 11.0 & 0.9 & 18.2 & 20.5 \\
\hline Return on asset (per cent) & -3.0 & 0.8 & 0.6 & 0.0 & 0.9 & 1.3 \\
\hline Total loans $(A)$ & 263.9 & 353.2 & 432.2 & 463.9 & 473.0 & 503.3 \\
\hline Substandard loans or below ${ }^{1}(B)$ & 19.0 & 11.7 & 10.6 & 13.1 & 9.4 & 6.5 \\
\hline Ratio to total loans (\%) (B/A) & 7.2 & 3.3 & 2.4 & 2.8 & 2.0 & 1.3 \\
\hline Loan loss reserve $(\mathrm{C})$ & 12.1 & 8.8 & 8.8 & 10.7 & 9.1 & 7.7 \\
\hline \multicolumn{7}{|c|}{ Reserves to substandard loans or below (\%) } \\
\hline$(\mathrm{C} / \mathrm{B})$ & 63.8 & 75.3 & 83.5 & 82.1 & 96.6 & 117.9 \\
\hline Capital adequacy ratio (BIS ratio) & 8.2 & 10.8 & 10.5 & 10.3 & 11.3 & 12.5 \\
\hline Number of branches & 4164 & 4052 & 4304 & 4345 & 4341 & 4415 \\
\hline
\end{tabular}

1. Includes loans classified as substandard, doubtful and estimated loss.

Source: Financial Supervisory Service.

Given Korea's high quality infrastructure and human capital, there is large scope for boosting the level of FDI in the service sector. The potential gains from such inflows appear important, given the service sector's lower level of productivity and growing share of the economy. ${ }^{2}$ Labour productivity in services in 2003 was only $64.8 \%$ of that in manufacturing, the largest gap in the OECD area, where productivity in the two sectors is roughly equal (Table 2). By international standards, sales turnover per employee is low, at $34 \%$ of the US level in design, $36 \%$ in legal and accounting, $44 \%$ in film, $52 \%$ in management consulting, and $61 \%$ in hospital care (LG Economic Research Institute, 2006).

Table 2. Employment, value-added and productivity by sector ${ }^{1}$

\begin{tabular}{|c|c|c|}
\hline & Korea & OECD \\
\hline \multicolumn{3}{|l|}{ Share of total employment, $2003(\%)^{2}$} \\
\hline Manufacturing (15-37) & 19.0 & 16.6 \\
\hline Services $(50-99)$ & 63.5 & 69.2 \\
\hline \multicolumn{3}{|l|}{ Share of total value added, $2003(\%)^{3}$} \\
\hline Manufacturing (15-37) & 26.4 & 17.9 \\
\hline Services (50-99) & 57.2 & 68.9 \\
\hline \multicolumn{3}{|l|}{ Value added per worker in 2003, manufacturing $=100^{2}$} \\
\hline Services $(50-99)$ & 64.8 & 97.1 \\
\hline Wholesale \& retail trade, hotels and restaurants $(50-52,55)$ & 28.1 & 70.5 \\
\hline
\end{tabular}

1. The numbers in parentheses show the ISIC (Rev.3) codes.

2. The OECD total is the simple average of 28 countries in which both employment and value added data are available for 2003 or the most recent year.

3. The OECD total is based on 30 countries, using data for the latest year available.

Source: OECD STAN Database for Industrial Analysis, 2006. 
Low productivity in the service sector is explained by a number of factors. First, industrial and tax policies favouring the manufacturing sector and exports of goods have penalised services. Second, entry barriers are generally higher in the service sector, weakening competition and resulting in a large number of small firms. Third, there is a large inflow of older workers into services, given the early age of retirement from firms (Jones, 2008). Lacking other alternatives, two-fifths of workers over the age of 55 are self-employed, primarily in the service sector. Consequently, one-third of workers in services are either self-employed or family workers compared to an average of $19 \%$ in the OECD area.

The Ministry of Finance and Economy announced a comprehensive plan in December 2006 to promote the service industry by providing support through tax policy, subsidies and deregulation. The plan identified 159 tasks to achieve three key objectives:

First, the business environment for the service industry is to be improved through better tax treatment and deregulation. For example, the comprehensive property tax will be cut for certain service industries, such as golf courses and hotels, and development charges (a quasi-tax) will be reduced for the service industry in non-metropolitan areas, as is currently the case for manufacturing. The tax credit for facility investment will be extended to more service industries and the cost of electricity for the service industry will also be lowered by about $30 \%$ to reach the level of the manufacturing sector by 2010. Furthermore, the government will provide additional cheap loans and financial subsidies to support investment in promising service industries. State-run banks will expand their capital pool for lending to service-sector companies from 3.2 trillion won in 2006 to 5 trillion won ( $0.6 \%$ of GDP) in 2007, while credit guarantees and export aid for the service sector are increased. A major step in the area of deregulation is the introduction of "Medical Service Organisations", which will allow hospitals to form networks with other hospitals and thereby achieve cost efficiencies and raise the quality of local hospitals by sharing facilities and brands.

Second, the government has identified 21 promising service industries, including video games, digital broadcasting, fashion and film, as priorities for enhancing growth and creating jobs. Detailed action plans, which are expected to include financial support and deregulation, were announced by each related ministry in 2007.

Third, the plan includes tax incentives and deregulation to promote the tourism and education sectors. One goal is to build an English-speaking town on Jeju Island in order to reduce demand for study-abroad programmes. As for tourism, the tax on developing facilities will be reduced to the level imposed on industrial complexes and administrative procedures will be streamlined.

The objectives of regulatory reform and equal treatment for the service sector relative to manufacturing are certainly positive steps. However, the playing field is still not level. In addition, the comprehensive plan raises some concerns. The measures to increase government lending, credit guarantees and export aid to the service sector raise moral hazard issues and distort the allocation of capital. The detailed action plans for 21 service industries should not include significant financial support by the public sector. Moreover, given that smaller firms play a significant role in many areas of the service sector, there is a risk that this initiative will undermine the government's goal of reducing the broad array of programmes to assist small and medium-sized enterprises (SMEs). In 2007, SMEs were supported by 174 different programmes, supervised by 12 different ministries, with total spending of 7.2 trillion won (0.8\% of GDP). In addition, two public institutions, the Korea Credit Guarantee Fund and the Korea Technology Guarantee Fund, guarantee loans to SMEs, with the total amounting to 39 trillion won (4.6\% of GDP) in 2006. The Bank of Korea has a longstanding guideline that $45 \%$ of lending by national banks and $60 \%$ by regional banks should go to the SME sector, which is highly indebted compared to large companies. Concern about rapid liquidity growth led the Bank to reduce policy lending to SMEs in December 2006 (see the 2007 OECD Economic Survey of Korea), conflicting with the new plan to expand lending to the service sector from state-owned banks.

1. The financial sector accounted for the largest share of FDI inflows in services, with 19\% between 2001-04. However, there are no foreign bank subsidiaries in Korea even though there are no restrictions in principle.

2. The share of value added in services increased from $49.5 \%$ of GDP in 1990 to $57.2 \%$ in 2003 .

5. However, the benefits from FDI have been limited by the small amount of inflows in Korea. Despite the increase since 1997, the stock of inward FDI relative to GDP was the sixth lowest in the OECD area in 2002 (Table 3). Korea's "inward FDI potential" is ranked 14th among OECD countries by UNCTAD. In contrast, Korea's performance, which compares actual inflows to its economic size, was ranked 24th in 2005, suggesting that there is a large scope for additional FDI in Korea. However, inflows 
declined from $\$ 9.3$ billion in 2004 to $\$ 6.3$ billion in 2005 (Figure 3), reducing Korea's share of world FDI inflows from $1.1 \%$ to $0.8 \%$ (Panel B). Inflows fell further to $\$ 3.7$ billion in 2006 . The unrealised potential and the declining trend suggest the need to address factors that act as barriers to FDI inflows and improve policies aimed at attracting foreign investors.

Table 3. Inward FDI position of OECD countries

\begin{tabular}{|c|c|c|c|}
\hline Countries $^{1}$ & $\begin{array}{c}\text { Stock in } 2002 \\
\text { (per cent of GDP) }\end{array}$ & $\begin{array}{l}\text { Inward FDI potential: }^{2} \\
\text { ranking among OECD } \\
\text { countries in } 2004\end{array}$ & $\begin{array}{l}\text { FDI performance: } \\
\text { ranking among OECD } \\
\text { countries in } 2005\end{array}$ \\
\hline Japan & 1.9 & 17 & 28 \\
\hline Iceland & 8.3 & 9 & 2 \\
\hline Italy & 9.6 & 20 & 22 \\
\hline Turkey & 10.2 & 29 & 19 \\
\hline Greece & 10.5 & 22 & 26 \\
\hline Korea & 11.5 & 14 & 24 \\
\hline United States & 12.8 & 1 & 25 \\
\hline Austria & 18.8 & 19 & 15 \\
\hline Norway & 19.5 & 4 & 21 \\
\hline Finland & 23.2 & 10 & 17 \\
\hline Mexico & 23.8 & 28 & 12 \\
\hline Germany & 24.1 & 6 & 27 \\
\hline France & 24.1 & 12 & 14 \\
\hline Poland & 25.0 & 26 & 7 \\
\hline Canada & 30.6 & 3 & 20 \\
\hline Australia & 30.7 & 13 & 23 \\
\hline Slovak Republic & 31.3 & 27 & 8 \\
\hline Portugal & 32.1 & 24 & 10 \\
\hline Spain & 32.3 & 18 & 13 \\
\hline United Kingdom & 33.8 & 2 & 5 \\
\hline Denmark & 38.3 & 16 & 29 \\
\hline Switzerland & 40.2 & 15 & 16 \\
\hline New Zealand & 41.8 & 21 & 11 \\
\hline Sweden & 44.3 & 5 & 9 \\
\hline Czech Republic & 48.3 & 25 & 3 \\
\hline Hungary & 54.4 & 23 & 4 \\
\hline Netherlands & 75.0 & 8 & 6 \\
\hline Belgium & 104.0 & 11 & 1 \\
\hline Ireland & 133.0 & 7 & 18 \\
\hline
\end{tabular}

1. Ranked in ascending order by FDI stock as a share of GDP.

2. Based on factors that affect an economy's attractiveness to foreign investors, such as real GDP growth, GDP per capita, total exports, energy use, education and R\&D expenditure.

3. Actual inflows relative to economic size.

Source: OECD (2005c), Economic Globalisation Indicators, OECD, Paris and UNCTAD (2006), World Investment Report 2006. 
ECO/WKP(2008)22

Figure 3. Inward FDI in Korea and its share of the world total

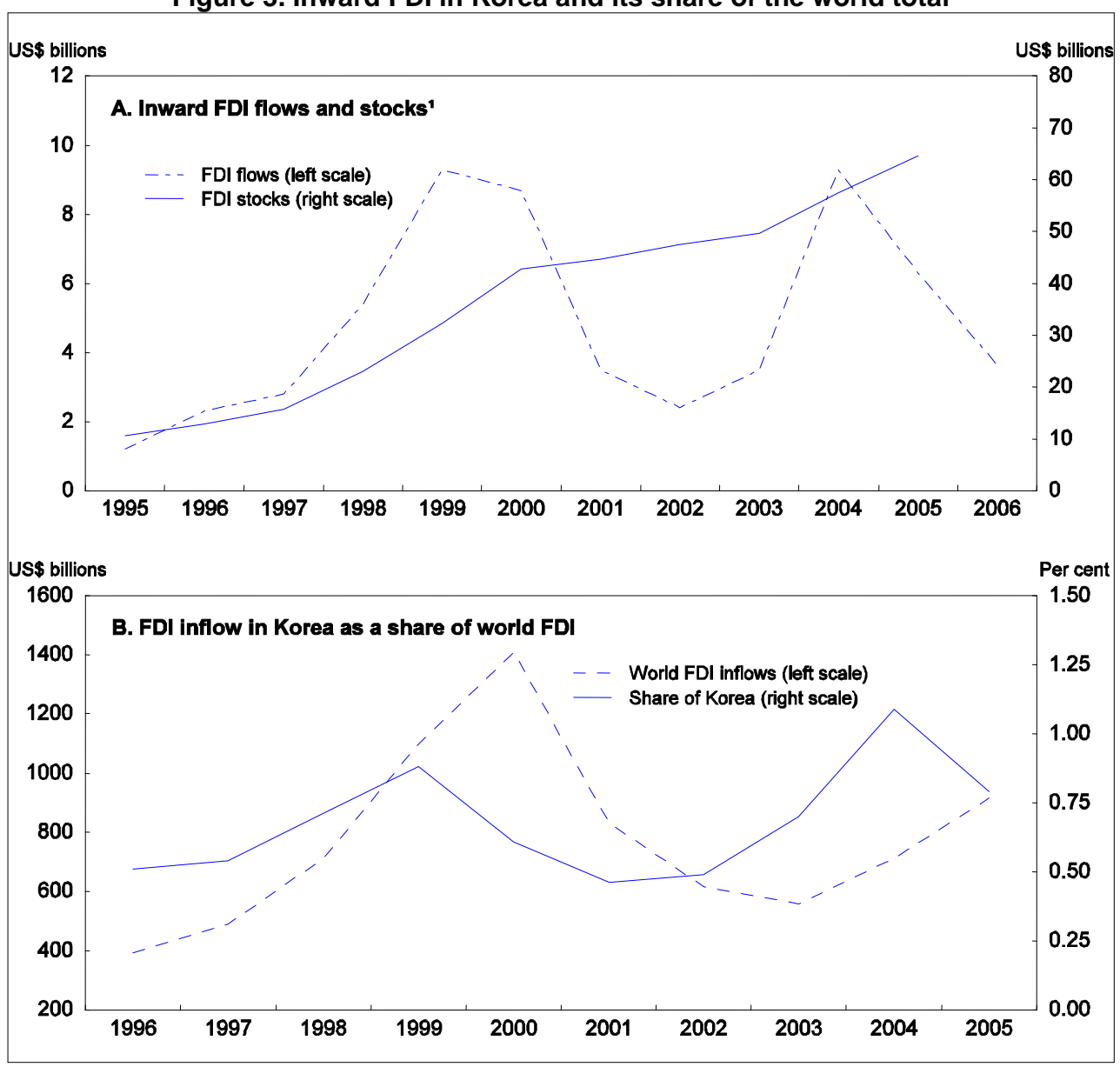

1. Actual basis.

Source: Ministry of Commerce, Industry and Energy, Bank of Korea and UNCTAD, World Investment Report 2006.

\section{Addressing factors that limit FDI inflows}

6. The conditions sought by foreign investors are largely equivalent to those that constitute a healthy business environment. The most important factors considered by firms include (OECD, 2003):

- A predictable and non-discriminatory regulatory environment and an absence of administrative impediments to business

- A stable macroeconomic environment

- High quality infrastructure and human capital

Many of these concerns are covered by the OECD's Policy Framework for Investment. ${ }^{3}$ Achieving such an environment is essential, as internationally mobile investors tend to respond quickly to changes in business conditions. To improve the environment in Korea for FDI inflows, the major tasks are to develop the M\&A market, further relax restrictions on FDI, ease product market regulations and improve the business and general living environment.

3. The 2006 Framework covered investment promotion policy, trade, competition and tax policies, corporate governance, policies for promoting responsible business conduct, human resource development, infrastructure and financial-sector development and public governance. 


\section{Activating the $M \& A$ market}

7. M\&A activity has emerged as the main driver of FDI flows. ${ }^{4}$ Korea experienced a surge in crossborder M\&As after 1997 as a result of the removal of restrictions and the restructuring of the corporate and financial sectors (Table 4). Subsequently, the amount decreased during 2000-02, before picking up during 2003-04. The telecommunication and financial sectors have accounted for much of the increase, reflecting high entry barriers in telecommunications and general financial regulations in the financial sector that make M\&As the preferred method of entering these markets. The share of M\&As by foreign firms in Korea's M\&A market has been around 30\% in recent years, close to the 36\% share of cross-border M\&As in the global total of M\&As. Cross-border M\&As accounted for $46 \%$ of total FDI in Korea during the period 2003 to 2005 .

8. The total M\&A market is relatively small in Korea, amounting to only $2.9 \%$ of market capitalisation in 2005, well below the United States (6.9\%), France (7.4\%), Germany (9.4\%) and the United Kingdom (9.9\%). ${ }^{5}$ Moreover, the share of M\&As by foreign firms in Korea amounted to only $1.5 \%$ of the world total of cross-border M\&As in 2005 (Table 4, Panel B). The small M\&A market partly reflects funding difficulties in Korea's still developing capital market and the negative attitude of management, labour unions and non-governmental organisations concerning M\&As. Such sentiments have been fuelled by the experiences of private equity funds that purchased Korean banks following the crisis ${ }^{6}$ and the active role of foreign shareholders.

9. The share of unsolicited takeovers in global cross-border M\&As doubled from $6 \%$ in 2005 to $12 \%$ in the first half of 2006 (Oh and Park, 2006). Although there has never been a successful unsolicited takeover bid for a Korean firm by foreign investors, three unsuccessful attempts launched since the crisis ${ }^{7}$ have prompted demands from Korean companies for increased protection from unsolicited takeover bids. Moreover, firms feel more vulnerable in the context of reduced restrictions on FDI (see below). Consequently, business groups have argued for the inclusion of poison pills, golden share and multiple voting rights in the Commercial Code to allow them to fend off unsolicited takeover bids. However, these demands were rejected on the grounds that they are inconsistent with global standards and violate the "equal treatment of shareholders" principle of the Code. The Federation of Korean Industries also argued for an end to the $25 \%$ shareholding ceiling imposed on chaebol-affiliated companies as it makes them more vulnerable to unsolicited takeover bids (Box 2).

4. The value of cross-border M\&As rose by $88 \%$ in 2005 , driving the increase in global FDI inflows. Crossborder M\&As accounted for 67\% of global FDI inflows in 2004-05 (UNCTAD, 2006).

5. Relative to GDP, the size of the M\&A market is also small in Korea at $2.2 \%$, compared to $7.1 \%$ in the United States and $11.9 \%$ in the United Kingdom (Oh and Park, 2006).

6. The two cases concern Newbridge Capital, which bought Korea First Bank in 1999 and sold it in 2005, and Lone Star, which bought Korea Exchange Bank (KEB) in 2003 and tried to sell it in 2006. Both claimed exemption from Korean taxes on their gains as they had established subsidiaries in countries with which Korea has bilateral tax treaties to avoid double taxation. In July 2006, Korea introduced a special withholding tax on third-country residents established in countries with such treaties to prevent them from benefiting from such treaties. However, investors can receive a refund if they subsequently prove that they are entitled to benefits under the treaty. In addition to the tax issue, there have been allegations that financial data on KEB had been understated to manipulate its stock price and lower the purchase price paid by Lone Star. These investigations forced Lone Star to terminate its proposed sale of KEB.

7. These include the bid for SK Telecommunication by the Tiger Fund in 1999 and for SK Corporation by Sovereign in 2003. In addition, Icahn made an unsolicited takeover bid for KT\&G in 2006. 
Table 4. Recent trends in the Korean M\&A marke

A. M\&As in Korea ${ }^{1}$ (trillion won)

\begin{tabular}{|c|c|c|c|c|c|c|c|c|c|}
\hline & & 1998 & 1999 & 2000 & 2001 & 2002 & 2003 & 2004 & 2005 \\
\hline \multirow[t]{2}{*}{ Total M\&As } & Case & 486 & 557 & 703 & 644 & 602 & 589 & 749 & 658 \\
\hline & Amount & 125.0 & 80.0 & 30.7 & 13.5 & 15.3 & 13.7 & 16.2 & 19.2 \\
\hline \multirow{3}{*}{ M\&As by foreign firms } & Share in total (\%) & 27.2 & 30.2 & 16.2 & 15.8 & 15.0 & 17.5 & 16.7 & 12.8 \\
\hline & Amount & 9.3 & 10.9 & 2.5 & 1.6 & 1.3 & 3.5 & 6.3 & 5.5 \\
\hline & Share in total (\%) & 7.4 & 13.6 & 8.1 & 11.9 & 8.5 & 25.5 & 38.9 & 28.6 \\
\hline
\end{tabular}

\section{B. World total by seller ( $\$$ billion)}

\begin{tabular}{|c|c|c|c|c|c|}
\hline \multicolumn{2}{|c|}{2003} & \multicolumn{2}{|c|}{2004} & \multicolumn{2}{|c|}{2005} \\
\hline Amount & Per cent & Amount & Per cent & Amount & Per cent \\
\hline 73.2 & 19.8 & 69.7 & 22.8 & 81.9 & 21.5 \\
\hline 5.7 & 1.5 & 11.0 & 3.7 & 8.9 & 2.3 \\
\hline 5.4 & 1.5 & 3.8 & 1.3 & 5.6 & 1.5 \\
\hline 49.0 & 13.3 & 65.6 & 22.1 & 66.3 & 17.4 \\
\hline 369.8 & 100.0 & 297.0 & 100.0 & 380.6 & 100.0 \\
\hline
\end{tabular}

1. M\&As include the transfer of business and equity acquisition. M\&As by foreign firms were not allowed until after the 1997 crisis.

2. Australia, Canada and New Zealand.

Source: Korea Fair Trade Commission and UNCTAD, World Investment Report, 2006. 


\section{Box 2. Recent reforms in the area of corporate governance}

Korea has made vigorous efforts since the crisis to improve corporate governance, such as expanding the rights of minority shareholders, strengthening the role of outside directors, requiring large business groups known as chaebol to produce consolidated financial statements, and stiffening penalties for improper disclosure. In addition, class action suits against large firms with assets of at least 2 trillion won were allowed in 2005 in securities-related cases. Nevertheless, the Korea Fair Trade Commission (KFTC) continues to impose extensive regulations on the corporate and financial structure of chaebol to limit the concentration of economic power and to improve corporate governance. ${ }^{1}$

One of the regulations limits shareholding in other companies by firms affiliated with the chaebol to $25 \%$ of their net assets. Despite holding only $6 \%$ of the groups' shares on average, the founding families of the large business groups have exercised significant control over affiliated firms through "circular shareholding". According to the KFTC, such a structure can undermine internal and external monitoring, disregard the interests of minority shareholders and create a risk that the bankruptcy of one subsidiary could drag down the entire conglomerate. Large business groups argue that this regulation is a major obstacle to business investment while making domestic companies vulnerable to unsolicited takeover bids. On the other hand, the KFTC believes that the regulation is not a serious obstacle to business investment as it is applied only to acquiring existing shares, and there has not been a significant correlation between increased shareholding by large business groups and subsequent investment.

The number of business groups subject to the shareholding ceiling, which was applied to business groups with more than 6 trillion won of assets, has been cut from 19 in 2002 to 14 in 2006, largely as a result of a graduation system based on corporate governance practices in 2004. Large chaebol are exempt from the regulation if they meet one of four conditions; 1) an excellent internal monitoring system; 2) a narrow gap between cash flows and voting rights; 3) a shareholding structure with five or less affiliates; or 4) adoption of a holding company structure. In practice, the coverage of this regulation is reduced by exemptions based on business needs, industry characteristics and government initiatives, including building "enterprise cities" (Jones and Yokoyama, 2008), attracting FDI, economic co-operation with North Korea and promoting industries identified as "growth engines". As a result, half of total shareholding by chaebol that would otherwise be subject to the regulation is exempted. In 2007, the National Assembly passed a bill to further reduce the coverage of the regulation by increasing the asset threshold while raising the shareholding limit.

Korea is taking further steps to improve corporate governance, ${ }^{2}$ such as extending the possibility of class action suits to all listed firms in 2007. In addition, amendments to the Commercial Code are to be proposed in 2007 to make managers and controlling shareholders more accountable to minority shareholders. Major changes under discussion include: 1) the introduction of "Double Derivative Lawsuits", which allow shareholders holding $1 \%$ or more of a parent company to sue directors of its subsidiary companies for breach of duty; 2) the "Executive Director System", which is intended to strengthen internal checks and balances by separating the supervisory role of boards of directors from that of executive directors focused on decision making; 3) a prohibition against corporate directors using their corporate responsibility for their own or a third party's benefit; and 4) subjecting transactions between corporations and their directors to greater review from the board of directors to prevent managers from pursuing personal interest at the expense of the firm. Although large business groups are critical of these measures, arguing that they would depress entrepreneurship and unduly undermine corporate autonomy, the enhanced Commercial Code should provide clear rules to help reduce many of the abuses that have occurred due to weak corporate governance practices. The strengthening of corporate governance should allow the phasing out of special regulations targeting the chaebol and allow the KFTC to focus more on competition policy. Supervisory functions related to shareholding, guarantees and intra-group transactions that amount to misuse of corporate assets should be concentrated in regulators responsible for financial and securities matters, notably the Financial Supervisory Service. Transactions that have an exclusionary or distorting effect on product market competition in particular cases should still be subject to competition-law control.

1. In addition to the shareholding ceiling, other major regulations include bans on cross-shareholding and cross-debt guarantees for affiliated companies, and a restriction on the voting rights of a financial company belonging to a chaebol to $30 \%$ regardless of its ownership share. These controls are applied to chaebol with assets of more than 2 trillion won.

2. According to a survey by the Korea Corporate Governance Service, the overall corporate governance framework is good but there is a need for better practice and enforcement, despite some improvement since 2003. 
10. Higher priority should be given to facilitating M\&As, given that Korea's market is still small. The authorities should explain the benefits of an active market for corporate control, while rejecting demands for legal changes to prevent unsolicited takeovers. At the same time, the government should ensure a level playing field between foreign and domestic firms, in part by removing the $25 \%$ shareholding ceiling. A more active M\&A market may help reduce the "Korea Discount" - the low price-earnings ratio for Korean firms compared to other countries ${ }^{8}-$ by prompting a revaluation of target firms. Indeed, the M\&A premium - the value of a firm in excess of its market price - is large in Korea. In addition, facilitating M\&A activity may improve weak corporate governance in chaebol. The threat of a potential M\&A adds pressure to develop well-structured corporate governance.

\section{Further liberalising restrictions on FDI inflows}

11. Lifting FDI restrictions to provide equal treatment of foreign and domestic investors is important to encourage inflows. The financial crisis prompted Korea to relax such restrictions through the Foreign Investment Promotion Act (FIPA) of 1998. The major measures included: 1) opening additional sectors to foreign investment. The number of business lines completely closed to FDI was reduced from 30 in 1997 to two at present - television and radio broadcasting - out of 1058 business lines; ${ }^{9}$ 2) eliminating restrictions on cross-border M\&As; 3) removing regulations on foreign ownership of real estate; 4) streamlining the registration of FDI from prior approval to notification. The FIPA also established the Committee on Foreign Direct Investment (CFDI) to make major policy decisions on FDI and prepare an annual FDI Environment Improvement Plan, based on proposals submitted by ministries and local governments, which are members of the Committee. Invest Korea was established in 2003 to provide a "one-stop service" to help foreign investors with administrative, legal and tax matters. In addition, the independent Foreign Investment Ombudsman was created to handle specific grievances by foreign investors, and in conjunction with Invest Korea, provides one-stop service to foreign investors.

12. Overall, formal FDI restrictions in Korea are judged to be slightly weaker than the OECD average, reflecting lower restrictions in manufacturing. ${ }^{10}$ However, investment in 26 sectors, primarily services, such as transport, telecommunications and electricity, are restricted by limits on foreign ownership. ${ }^{11}$ As a result, the OECD index of FDI restrictions in these sectors is above the average of member countries. Reducing FDI restrictions is likely to significantly increase Korea's stock of inward FDI. ${ }^{12}$ In addition to network industries, it is important to open public social services, such as education and healthcare, to FDI inflows to enhance productivity and efficiency in these key areas.

13. Product market regulations (PMRs) - regulations that have the potential to reduce competition in all sectors - have been found to impose significant barriers to FDI in OECD countries. Moreover, they have become relatively more significant obstacles as explicit restrictions on FDI have been gradually

8. The average price-earnings ratio of listed companies in the Korean stock market in 2005 was 11.2 , compared to an average of 12.6 in China, 14.8 in Taipei, China, 15.6 in Malaysia, 16.0 in Hong Kong, China,16.5 in Singapore and 18.0 in India (Jang, 2006). This is usually attributed to weak corporate governance practices in Korea.

9. The 1058 business lines exclude public services such as postal services and education.

10. Korea was rated at 0.12, compared to an OECD average of 0.148 (Golub and Koyama, 2006).

11. The ceiling on foreign equity is $50 \%$ in power distribution and transmission, air transport, fishing and beef cattle, $49 \%$ in telecommunications and $33 \%$ in cable and satellite broadcasting. The latter restriction was strengthened in 2006 by requiring potential purchasers of more than a $15 \%$ stake in a telecommunications firm to receive prior approval from the Ministry of Information and Communications.

12. Nicoletti et al. (2003) estimated that reducing the level of restriction in Korea to that in the least restrictive country (the United Kingdom) would boost Korea's stock of FDI by $40 \%$. 
eliminated. Empirical studies show that countries with relatively restrictive and costly product market regulations tend to have lower stocks of foreign investment (Nicoletti et al., 2003). ${ }^{13}$ According to the OECD indicator, inward-oriented regulations in Korea were near the OECD average in 2003 (Figure 4). In the "state control" sub-category, Korea's regulations are rated as more liberal than the OECD average, reflecting the progress in privatisation since the crisis. ${ }^{14}$ However, Korea's regulations were ranked as relatively restrictive in the "barriers to entrepreneurship" sub-category, which includes regulatory opacity, administrative burdens on start-ups and barriers to competition. As for the service sector, Korea was ranked as the fifth most restrictive country. Restrictive PMRs and regulations on foreign ownership in some sectors help to explain why the share of Korea's FDI stock in services is one of the lowest in the OECD area.

14. In particular, regulations restricting new investment in the capital region, which are intended to promote balanced national growth (Jones and Yokoyama, 2008), are frequently cited as a major obstacle to FDI. The preference of foreign investors for the capital region, given its high quality infrastructure, the availability of skilled human resources and access to a large market, conflicts with the government's objective of developing other parts of the country. The authorities temporarily exempted foreign investment in 25 high-technology industries from these restrictions, while also allowing exemptions for domestic firms in eight industries. Nevertheless, each foreign investment proposal still requires approval from the relevant ministries, based on its overall contribution to the economy. The case-by-case approach undermines the transparency of the FDI framework, thereby driving away potential investors. Transparency should be enhanced by introducing clear criteria, while lifting the capital-region regulations.

\section{Improving the business and living environment}

15. A 2006 poll of foreign firms identified the main problems in the business environment in Korea (Table 5). In the survey, labour-management relations are the major concern cited by foreign firms in Korea. The relationship between employers and employees is often marked by struggle and confrontation rather than dialogue and compromise. Indeed, the number of working days lost due to labour strikes in Korea averaged 100 days per 1000 workers between 2000-03, the sixth highest in the OECD area and significantly above other Asian countries (Figure 5). Although the number of strikes has fallen during the past two years, the number of days lost remained high at 77 days per 1000 workers in 2006. Of the 280 foreign firms surveyed, $49 \%$ were dissatisfied with labour-management relations - the largest share for any issue - while only $19 \%$ were satisfied. Other labour market problems cited by foreign affiliates include the demand of workers to participate in management, a complicated wage structure, the retirement allowance system, the requirement to pay labour union leaders and limits on the duration of contracts for dispatched workers. Another concern is employment protection, which makes corporate restructuring difficult and raises costs by limiting managerial discretion. ${ }^{15}$ The lack of flexibility in restructuring may undermine the rationale for M\&As, thus tending to reduce FDI inflows.

13. An OECD study showed that product market reform would provide larger gains in GDP per capita than lowering tariff rates and obstacles to FDI. Aligning the stance of domestic regulations on that in the least restrictive country leads to an increase in GDP per capita of $1.75 \%$ to $3 \%$ in the OECD area while the impact of lowering barriers to FDI is $0.75 \%$ and that of cutting tariff rates is $0.25 \%$ to $1 \%$ (OECD, 2005a).

14. Eight of the 11 state-owned enterprises (SOEs) identified for privatisation in 1998 have been fully privatised while the remaining three - Korea Electronic Power Corporation (KEPCO), Korea Gas Corporation (KOGAS) and the Korea District Heating Corporation - are still to be privatised.

15. The first priority of the U.S.-Korea Business Council in the area of labour is "Ensuring management's ability under Korean labor regulations to react quickly to fluctuations in global and local demand and competitive pressure through hiring, dismissing, and transferring employees at management's discretion". 
Figure 4. Product market regulation in $2003^{1}$

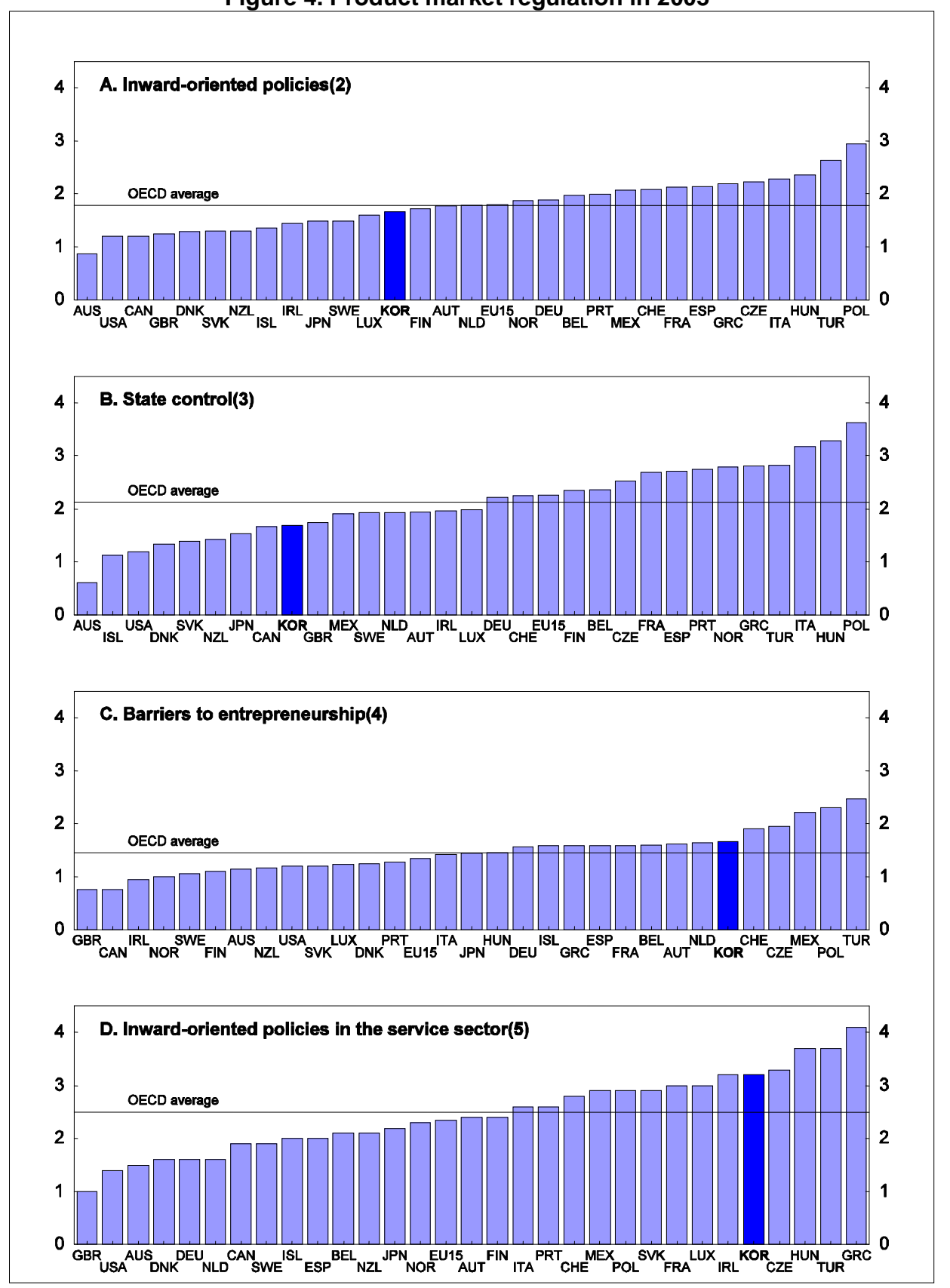

1. The scale of indicators is 0-6 from least to most restrictive. OECD and EU15 are simple averages.

2. Inward-oriented policies consist of "State control" and "Barriers to entrepreneurship", excluding barriers to trade and investment.

3. State control covers public ownership of business enterprises and government's involvement in business operations.

4. Barriers to entrepreneurship cover regulatory and administrative opacity, administrative burdens on start-ups and barriers to competition, including entry barriers.

5. Includes electricity, gas, airlines, rail and road transport, post and telecoms. Barriers to trade and investment are not included.

Source: Conway et al. (2005). 


\section{ECO/WKP(2008)22}

16. The government has made progress in bringing Korea more closely in line with international labour standards in implementing the 2003 "Roadmap for Industrial Relations Reform". ${ }^{16}$ The main outstanding questions are allowing multiple unions at the enterprise level and the prohibition on companies paying union leaders. The Tripartite Commission, consisting of unions, management and government officials, agreed to delay the introduction of multiple unions and the ban on paying union leaders until 2009. Despite the progress in implementing the Roadmap, a national labour confederation has launched a number of general strikes focused on several issues, including the Korea-US free trade agreement (see below). Moreover, the issue of employment flexibility for regular workers has not been addressed.

17. Another criticism of the business climate in Korea concerns administrative transparency. Foreign firms complain about a lack of transparency and predictability in tax and financial supervisory policies, especially at the enforcement level, and believe that rules are interpreted more strictly for foreign companies (OECD, 2007a). This is a result of enforcement based on internal regulations and wide discretion at the working-level staff. Despite government efforts to improve transparency, a 2006 poll of foreign firms by Invest Korea reported that 58\% saw no change and 19\% saw a deterioration in the situation.

Table 5. Korea's business environment: the view of foreign firms

Response to the question: "What is the most important task to improve the business environment?"1

\begin{tabular}{lc}
\hline & Per cent \\
Address problems in labour-management relations & 34.6 \\
Create an international mindset & 31.1 \\
Open markets & 22.5 \\
Expand the use of foreign languages & 13.9 \\
Alleviate the excessive tax burden & 13.2 \\
Ensure transparent business practices & 12.9 \\
Strengthen administrative support for services & 12.1 \\
Foster a freer and more international financial environment & 10.7 \\
Ensure political stability & 8.9 \\
Refurbish the logistical environment & 6.1 \\
Other & 2.1 \\
No response & 0.4 \\
\hline
\end{tabular}

1. A survey of 280 foreign firms operating in Korea.

Source: Invest Korea (2006).

16. Four of the six issues identified in the 2005 follow-up study on Korea's industrial relations by the OECD's Directorate for Employment, Labour and Social Affairs have been resolved. First, trade unions for public officials were allowed in 2006. Second, the definition of essential public services was narrowed and the practice of mandatory arbitration was replaced by ensuring minimum services. Third, unemployed persons are now allowed to become union members. Fourth, the requirement for notification of third parties in industrial disputes was abolished. 
Figure 5. Working days lost due to strikes

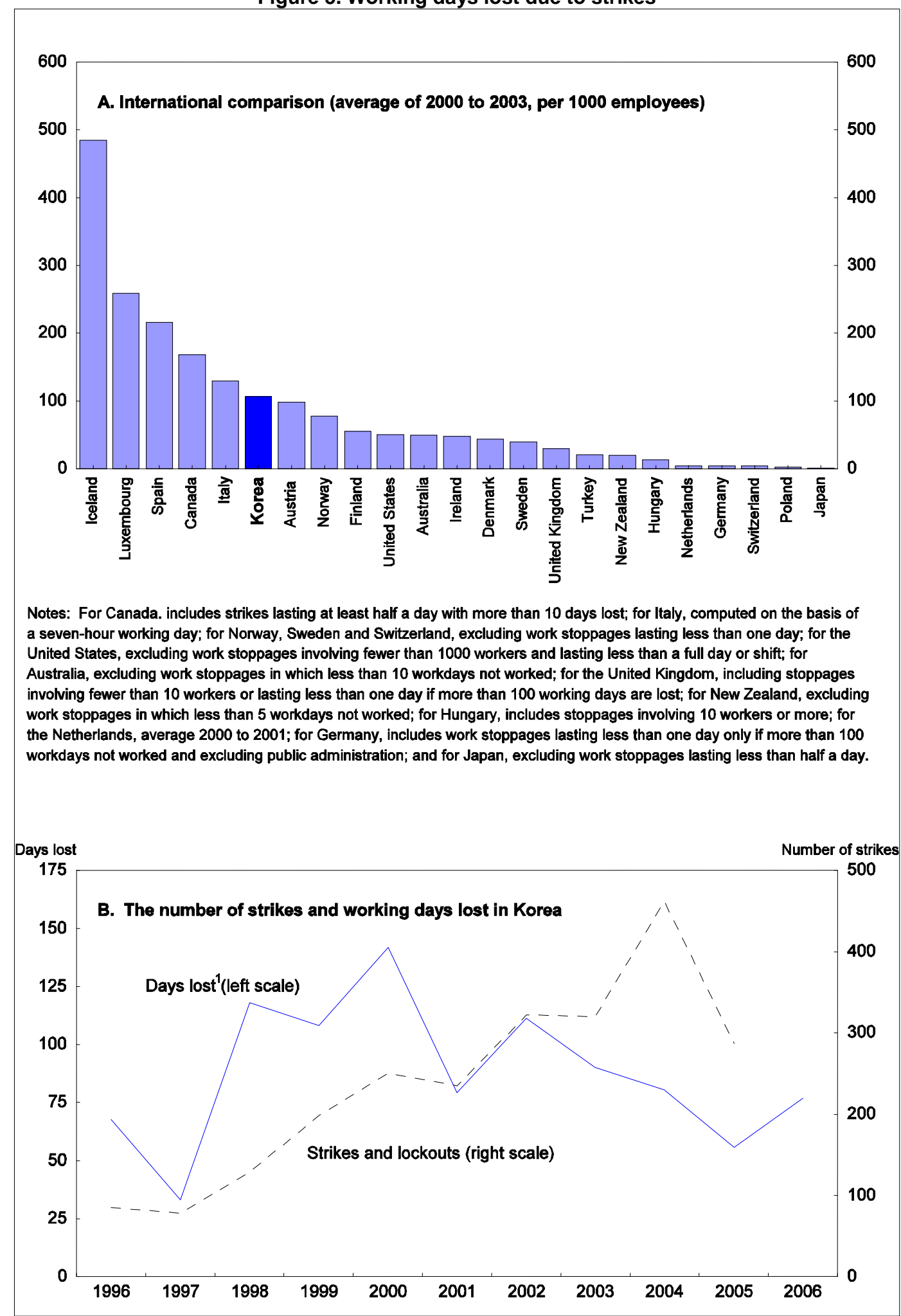

1. Per 1000 employees.

Source: International Labour Organisation, Yearbook of Labour Statistics. 


\section{ECO/WKP(2008)22}

18. Another important factor in FDI decisions is the quality of life for foreigners, including access to high quality foreign schools and hospitals. In Korea, firms, whether domestic or foreign, are not allowed to establish schools or hospitals for profit. To improve the living environment for foreigners, the Korean government recently allowed foreign hospitals and schools in the Free Economic Zones (see below). However, the repatriation of earnings from schools is banned, effectively discouraging foreign schools from entering the zones. Allowing both domestic and foreign firms to enter the education and healthcare markets on a nation-wide basis would improve living conditions throughout the country. In 2004, the government announced a five-year plan to promote a more friendly business and living environment for foreign investors. It identified 156 tasks, including immigration procedures, residential facilities and access to high quality schools and medical facilities. By the end of 2006, 108 of the tasks had been addressed, with the remainder to be completed by 2008 .

\section{Incentives for FDI inflows}

19. Many countries offer incentives ${ }^{17}$ that discriminate in favour of foreign firms, reflecting the view that the return on FDI is higher than that on other sources of investment. However, such incentives risk reducing global welfare by shifting capital away from where it is most productive to jurisdictions paying the highest subsidies. This results in investment projects that would not be viable without subsidies.

20. Even if FDI does provide important spill-over benefits, financial incentives are not the best option to attract investors. As noted above, foreign investors focus primarily on the quality of the business and living environment. The use of tax incentives, financial subsidies and regulatory exemptions to attract FDI is no substitute for measures to improve the business environment, which would at the same time encourage domestic investment. There is a rationale for incentives aimed at compensating for structural problems that cannot be quickly remedied. However, there are risks to using incentives. First, the incentives can distract policymakers from the more important task of addressing the structural problems that deteriorate the business environment. Second, offering incentives selectively to foreign investors risks hurting the environment for domestic firms. This is especially the case in Korea, given its abundant private savings and many potential domestic investors. In sum, the cost of moving away from a level playing field, which include distortions in the allocation of capital, have to be weighed against the economic benefits of incentives (OECD, 2003).

21. Korea has implemented various policy initiatives to attract FDI inflows since 1970 and these efforts have been strengthened since the financial crisis. In particular, there are four types of special zones aimed at encouraging FDI (Table 6): Foreign Investment Zones (FIZ) type A, which can be located anywhere in the country (at present there are 24); eleven FIZ type B (industrial complexes); nine Free Trade Zones (FTZ) and; three Free Economic Zones (FEZ). Tax incentives are a key aspect of each type of zone. $^{18}$ Incentives are primarily aimed at knowledge intensive and high value-added industries that promote innovation (Box 3).

22. FDI incentives should be evaluated regularly to ensure that their economic benefits exceed their fiscal costs. For example, foreign investors in the special zones receive tax holidays and rent subsidies. Tax expenditures resulting from FDI incentives for income and corporate tax alone jumped from 44 billion won in 1999 to 550 billion won ( $0.1 \%$ of GDP) in 2005. Evaluations require transparency and accountability, as well as estimates of the impact of incentives. It is important to avoid deadweight costs, i.e. subsidising

17. Incentives are defined as measures designed to influence the size, location or industry of a FDI project by cutting its relative cost or by reducing risks through inducements not available to domestic firms.

18. This reflects concern about the relatively high corporate tax rate in Korea at 25\%, compared to China (15\%), Hong Kong (17.5\%) and Singapore (20\%). 
investments that would have occurred without incentives. In addition, the authorities should consider opportunity costs, which arise from more effective alternative uses (OECD, 2003).

23. There are concerns about the effectiveness of Korea's special zone initiatives to attract FDI. First, despite the government's efforts to consolidate and streamline different special zones, ${ }^{19}$ the availability of four different types of zones and the fact that some of the zones overlap geographically ${ }^{20}$ complicate the FDI regime and may confuse potential foreign investors. The rationale for different incentives and eligibility requirements for the same type of investment projects is not clear. ${ }^{21}$ The objective should be to create a coherent framework of incentives that provides the same, or at least a similar, level of incentives between zones. Setting a fixed duration for incentives would encourage regular evaluation, thus helping to limit the number of different types of zones.

24. Second, there is concern about the effectiveness of incentives for FDI. For example, even though each FEZ has a planning office under local government, foreign firms still need to get individual approval from some national ministries. In particular, the regulations on construction in the capital region, which classify land into three zones (congestion restraint, growth management and nature conservation), are a serious obstacle to developing the Incheon FEZ. Part of the Incheon FEZ is classified as a congestion restraint zone, subjecting it to stricter approval procedures. Furthermore, domestic firms, except SMEs, are not allowed to invest in congestion restraint zones. Such restrictions have a negative impact on attracting foreign firms that wish to foster close ties with Korean companies. Discriminatory regulations against domestic firms should be lifted to ensure a level playing field with foreign companies. The regulations allowing foreign investment in social services, such as healthcare and education, should be extended beyond the FEZs and allowed for domestic firms as well. Rather than offering preferential regulatory treatment in the FEZs, it would be beneficial to relax regulations that discourage foreign investors throughout the country. Finally, investment promotion agencies, such as the planning offices for the FEZs, should act as "one-stop service" agencies.

25. Third, while the use of front-loaded benefits, such as cash grants, on a case-by-case basis enhances flexibility in providing incentives, it also reduces transparency since negotiations are confidential. In addition, it increases the risk that the grants will be larger than the benefits of additional FDI.

26. Fourth, FDI incentives focus mainly on the manufacturing sector, despite the government's commitment to make Korea a financial and business hub in Northeast Asia and foreign firms' growing interest in services. At present, the only services eligible for FDI incentives are tourism, logistics and R\&D.

19. The government consolidated "Customs Free Zones", which focused on attracting FDI in the logistics sector, into the FTZs in 2004. In addition, in 2005, it incorporated "Industrial Complexes for Foreign Firms" into the FIZ scheme, changing its name to FIZ type B and strengthening tax incentives to the level of the FEZs and FTZs.

20. For example, the Daebul industrial complex includes both a FIZ type B and a FTZ, with the Gwangyang Bay FEZ located nearby.

21. For example, in FIZ type A zones, the minimum FDI level for a tax incentive is $\$ 30$ million in manufacturing, \$20 million in tourism and \$10 million in logistics while in the FIZ type B and FEZ, the minimum level is only $\$ 10$ million in manufacturing and tourism, and $\$ 0.5$ million in logistics. In addition, the duration of incentives differs. A foreign investment project in manufacturing is eligible for seven years of tax breaks in FIZ type A zones, but only five years in other zones. 
Box 3. Policy initiatives to encourage inward FDI

The development of four different types of zones (Table 6) reflects the introduction of new types of zones to attract investors while maintaining existing zones. For example, the FIZ type A, which allows flexibility in the location of FDI, were introduced in 1999 to address the unattractiveness of the pre-designated industrial complexes (FIZ type B) created in 1994. Indeed, the occupancy ratio of these zones is only $59 \%$. The introduction of new zones with stronger incentives and a better business environment make existing zones unattractive to investors.

The FEZs were introduced in 2003 in response to demand from investors for an improved business and living environment. The three regions designated as FEZs thus far - Incheon, Busan/Jinhae and Gwangyang Bay - are still in the initial stage of developing infrastructure, with less than $\$ 1$ billion in investment by the end of 2006 . A number of incentives have been introduced to encourage investment in the FEZs. For example, foreign companies in the zones are exempted from quotas on employing veterans, the disabled and the elderly and are allowed to build hospitals in the zones, which is not allowed elsewhere in the country except in "enterprise cities" (2007 OECD Economic Survey of Korea). In addition to the tax incentives, foreign investors receive rent subsidies of up to $100 \%$ on state land and may receive cash grants for investments of over $\$ 10$ million in high technology and parts and material, and over $\$ 5$ million in R\&D facilities. The grant is negotiated on a case-by-case basis, taking into account spill-over effects, job creation and the level of technology. The overall incentives for FDI, including tax breaks, cash grants and subsidies for land use, can be as high as $20 \%$ of total investment (Nam and Yoon, 2006). 
ECO/WKP(2008)22

Table 6. Special zones to encourage FDI inflows

\begin{tabular}{|c|c|c|c|c|}
\hline & $\begin{array}{c}\text { Foreign investment zones } \\
\text { (Type A) }\end{array}$ & $\begin{array}{l}\text { Foreign investment zones } \\
\text { (Type B) }\end{array}$ & Free economic zones & Free trade zones \\
\hline Year introduced & 1999 & 1994 & 2003 & 1970 \\
\hline Number & $\begin{array}{l}24 \text { (located anywhere in the } \\
\text { country) }\end{array}$ & 11 & 3 & 9 \\
\hline \multirow[t]{3}{*}{ Eligibility for tax incentives } & $\begin{array}{l}\text { Manufacturing (more than } \\
\$ 30 \text { million) } \\
\text { High technology (more } \\
\text { than } \$ 30 \text { million) } \\
\text { Industry-supporting services } \\
\text { (more than } \$ 30 \text { million) }\end{array}$ & $\begin{array}{l}\text { Manufacturing (more than } \\
\$ 10 \text { million) }\end{array}$ & $\begin{array}{l}\text { Manufacturing (more than } \\
\$ 10 \text { million) }\end{array}$ & $\begin{array}{l}\text { Manufacturing (more than } \\
\$ 10 \text { million) }\end{array}$ \\
\hline & $\begin{array}{l}\text { Tourism (more than } \\
\$ 20 \text { million) }\end{array}$ & & $\begin{array}{l}\text { Tourism (more than } \\
\$ 10 \text { million) }\end{array}$ & \\
\hline & $\begin{array}{l}\text { Logistics (more than } \\
\$ 10 \text { million) } \\
\text { R\&D (more than } \$ 0.5 \text { million) }\end{array}$ & $\begin{array}{l}\text { Logistics (more than } \\
\$ 0.5 \text { million) }\end{array}$ & $\begin{array}{l}\text { Logistics (more than } \\
\$ 0.5 \text { million) }\end{array}$ & $\begin{array}{l}\text { Logistics (more } \\
\text { than } \$ 0.5 \text { million) }\end{array}$ \\
\hline Tax incentives $^{1}$ & $\begin{array}{l}100 \% \text { exemption for } 5 \text { years, } \\
50 \% \text { for } 2 \text { years }^{2}\end{array}$ & $\begin{array}{l}100 \% \text { exemption for three } \\
\text { years, } 50 \% \text { for } 2 \text { years }\end{array}$ & $\begin{array}{l}100 \% \text { exemption for three } \\
\text { years, } 50 \% \text { for } 2 \text { years }\end{array}$ & $\begin{array}{l}100 \% \text { exemption for three } \\
\text { years, } 50 \% \text { for } 2 \text { years }{ }^{2}\end{array}$ \\
\hline Other taxes ${ }^{3}$ & $\begin{array}{l}100 \% \text { exemption for capital } \\
\text { goods }\end{array}$ & $\begin{array}{l}100 \% \text { exemption for } \\
\text { capital goods }\end{array}$ & $\begin{array}{l}100 \% \text { exemption for capital } \\
\text { goods }\end{array}$ & $\begin{array}{l}100 \% \text { exemption for imported } \\
\text { goods }\end{array}$ \\
\hline Rent support & $100 \%$ for 50 years & 75 to $100 \%{ }^{4}$ & Up to $100 \%$ & $100 \%^{5}$ \\
\hline
\end{tabular}

1. Exemptions applied to national taxes, such as corporate and income taxes, and local taxes, such as property, registration and acquisition taxes.

2. Can be extended up to 15 years for local taxes.

3. Customs duties, special consumption tax and value-added tax

4. $100 \%$ for high-tech industry with investment of more than $\$ 1$ million. $75 \%$ for manufacturing firms with investment of more than $\$ 5$ million.

5. $100 \%$ for high technology firms with investment of more than $\$ 0.5$ million and other industries with more than $\$ 1$ million.

Source: Ministry of Commerce, Industry and Energy. 


\section{Deepening international integration through trade}

27. Import penetration in Korea, defined as imports of manufactures divided by domestic demand, in Korea is one of the lowest in the OECD area (Figure 6). Moreover, it rose less than 1 percentage point between 1995 and 2003, compared to a 9 percentage-point average increase in the OECD area. Nevertheless, the level of imports appears to be consistent with expected levels, taking into account country size, transport costs and per capita income (OECD, 2006c). Import penetration, though, could be boosted by reductions in trade barriers. Meanwhile, export intensity (exports as a share of domestic production) has increased significantly during the past decade.

\section{Figure 6. International comparison of import penetration}

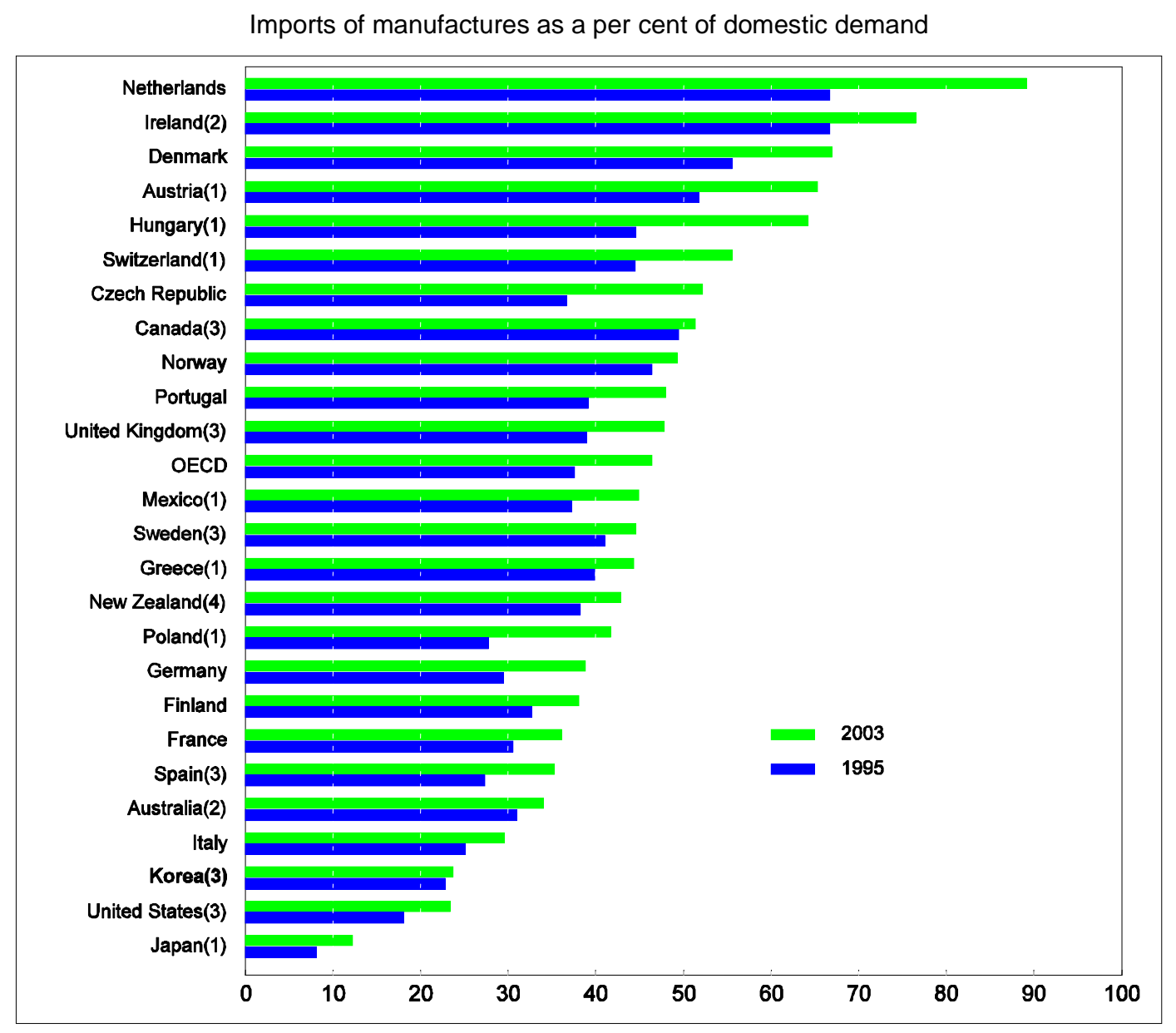

1. Data for Austria, Greece, Hungary, Japan, Mexico, Poland and Switzerland refer to 2002.

2. Data for Australia and Ireland refer to 1999.

3. Data for Canada, Korea, Spain, Sweden, United Kingdom and United States refer to 2001.

4. Data for New Zealand refer to 1998.

Source: OECD (2005c), Economic Globalisation Indicators, OECD, Paris. 


\section{Promoting trade liberalisation}

28. One major factor influencing trade flows is trade protection. In terms of tariffs, Korea's simple average rate is more than double that in other major OECD regions, reflecting very high rates on agricultural products (Table 7). In contrast, the average rate on other products is more in line with other OECD countries, while the extent of non-tariff barriers - quantitative controls, finance measures and price controls - appears to be relatively low, again with a sharp difference between manufactures and nonmanufactures (Bora et al., 2002). However, differences between countries in standards can also limit imports. Of the 21251 Korean standards, $60 \%$ are subject to international harmonisation. The proportion varies significantly, from $93 \%$ for information technology to $23 \%$ for household goods. Foreign firms argue that standards unique to Korea pose a barrier to imports, notably in some industries such as food products and cars. Moreover, labelling, testing and certification procedures are considered to be unfair in areas such as pharmaceuticals (OECD, 2007a). Further reducing and harmonising voluntary standards and mandatory technical regulations with international norms would increase openness to imports.

Table 7. International comparison of tariffs

Simple average of applied MFN tariff rates in $2004^{1}$

\begin{tabular}{lrrr}
\hline & Total & Agricultural products & Non-agricultural products \\
\cline { 2 - 4 } Korea & $\mathbf{1 2 . 8}$ & $\mathbf{5 2 . 2}$ & $\mathbf{6 . 7}$ \\
United States & 4.9 & 9.7 & 4.0 \\
European Union & 6.5 & 16.5 & 4.1 \\
Japan & 6.3 & 17.7 & 3.7 \\
\hline
\end{tabular}

1. WTO definitions for agricultural and non-agricultural products.

Source: World Trade Organisation.

29. The number of bilateral and regional free trade agreements (FTAs) in force reported to the World Trade Organisation has soared from 27 in 1990 to nearly 200. However, Korea did not belong to any such agreements prior to 2004, as it focused on the multilateral trading system. The increasing emphasis in Korea on FTAs marks a shift toward a two-pronged trade policy (Table 8). Korea's first FTA was with Chile, followed by Singapore, the European Free Trade Association (EFTA) and ASEAN (covering goods only). Negotiations with the United States were successfully concluded in April 2007. At present, Korea is pursuing a multi-track approach, negotiating FTAs with Canada, India, Mexico and the European Union. In addition, Korea has completed joint studies with MERCOSUR at the government level and China at the private level. Korea's long-term objective is to conclude FTAs with large economic blocs.

30. Korea's objective in pursuing FTAs is to revitalise its economy by liberalising its trade and investment regime, while securing better access to foreign markets. FTAs are expected to boost output growth through dynamic gains from capital formation and increased productivity, in addition to static gains in efficiency by prompting the restructuring of less competitive sectors. The Korea-US FTA is projected to increase GDP by as much as $2 \%$ in the long run (KIEP, 2006). Furthermore, FTAs should improve the FDI climate by expanding the scope of the market and reducing operating costs, thus providing better opportunities to foreign investors. A comprehensive agreement with the United States would add considerable momentum to regulatory reform in the service sector. 
Table 8. Korea's FTA strategy

\begin{tabular}{|c|c|c|c|c|c|}
\hline \multirow[t]{2}{*}{ Country } & \multirow[t]{2}{*}{ Status } & \multicolumn{2}{|c|}{$\begin{array}{l}\text { Share of exports in } \\
2005 \text { in per cent }\end{array}$} & \multicolumn{2}{|c|}{$\begin{array}{l}\text { Share of imports in } \\
2005 \text { in per cent }\end{array}$} \\
\hline & & Total & Agriculture & Total & Agriculture \\
\hline Chile & Signed in 2003 and took effect in 2004 & 0.4 & 0.0 & 0.9 & 0.6 \\
\hline Singapore & Signed in 2005 and took effect in 2006 & 2.6 & 1.1 & 2.0 & 0.3 \\
\hline EFTA & Signed in 2005 and took effect in 2006 & 0.4 & 0.1 & 0.7 & 0.3 \\
\hline ASEAN & Signed only on trade in goods in 2006 & 9.6 & 6.5 & 10.0 & 10.6 \\
\hline United States & Negotiations were completed in 2007 & 14.5 & 12.5 & 11.7 & 21.0 \\
\hline Canada & Negotiations are underway & 1.2 & 1.3 & 1.0 & 3.6 \\
\hline India & Negotiations are underway & 1.6 & 0.2 & 0.8 & 1.8 \\
\hline Mexico & Negotiations are underway & 1.3 & 0.1 & 0.2 & 0.2 \\
\hline Japan & Negotiation stopped since 2005 & 8.4 & 32.7 & 18.5 & 2.0 \\
\hline EUं & Negotiations are underway & 15.4 & 2.4 & 10.4 & 11.1 \\
\hline MERCOSUR & $\begin{array}{l}\text { Joint study at government level was completed } \\
\text { in } 2006\end{array}$ & 1.0 & 0.2 & 1.1 & 11.0 \\
\hline China & Joint study at private level was completed in & & & & \\
\hline & 2006 & 21.8 & 9.7 & 14.0 & 23.8 \\
\hline
\end{tabular}

Source: MOFAT, Korea International Trade Association and Korea Agricultural Trade Information.

\section{Opening the agriculture sector}

31. Despite the strong commitment to achieve FTAs with major trading partners, the priority attached to protecting sensitive areas - primarily the agriculture sector - substantially limits the positive economic impact on Korea. One reason is that it weakens the negotiating leverage to open up markets for manufactures, where Korea has a competitive advantage. Under the Korea-Chile FTA, Korea permanently excluded the possibility of lower tariffs on 21 important agricultural items such as rice, apples, and pears. ${ }^{22}$ Moreover, tariff reductions on 373 agricultural tariff lines, including vegetables, grains, livestock, dairy products and fruit, were temporarily excluded. ${ }^{23}$ As a result, most of the decline in the average tariff rate imposed on imports from Chile was due to reductions on manufactured products. ${ }^{24}$ In contrast, the average agricultural tariff on imports from Chile after the FTA remains high at 50\% (WTO Trade Policy Review, 2004), roughly in line with Korea's overall average on agricultural products (Table 7). Similarly, in the FTA with ASEAN, at least $90 \%$ of tariff lines are scheduled to be liberalised by 2010 , with agricultural products (including forest and fishery products) accounting for most of the remaining $10 \%$. Agricultural products were also largely excluded from the FTAs with Singapore and EFTA, although this was not a controversial issue, reflecting the small portion of agricultural trade between Korea and these countries.

32. The reluctance to open up the agricultural market reflects the high level of agricultural support, especially for rice. ${ }^{25}$ Korea's agricultural support exceeds the sector's relatively small GDP contribution ${ }^{26}$

22. Based on the HS 10-digit level.

23. Chile permanently excluded 54 tariff items, such as refrigerators, washing machines, sugar and wheat.

24. The Korea-Chile FTA provided for immediate tariff-free access in $87 \%$ of tariff lines by Korea and $41 \%$ by Chile, which corresponds to $77 \%$ of Chilean exports to Korea and $67 \%$ of Korean exports to Chile.

25. Protection is aimed at achieving some degree of self-sufficiency. Self-sufficiency ratios on crops averaged $29.3 \%$ in 2005 , ranging from $101.7 \%$ for rice, $60.8 \%$ for barley, $8.5 \%$ for soybeans, $0.9 \%$ for corn, $0.2 \%$ for wheat and $7.7 \%$ for other crops.

26. The share of agriculture, forestry and fisheries fell from 4.9\% of GDP in 2000 to an average of 3.3\% between 2003-05. This is below the "Total Support Estimate" of 26.3 trillion won (3.5\% of GDP) over the 
and is among the highest in the OECD, with a Producer Support Estimate (PSE) of $62 \%$ in 2003-05, double the OECD average (Figure 7). As a result of such heavy protection, Korean consumers paid 2.5 times the world price on average for agricultural commodities between 2003 and 2005, as indicated by the Nominal Protection Coefficient shown in Panel B. Rice alone accounts for almost one-third of the PSE. Most of the support for agriculture is provided through market price supports, the most distortive form of support, as they alter production and trade decisions and limit the influence of world markets on domestic production decisions. This results in surplus production of key commodities, such as rice and dairy products. The share of market price supports fell slightly from $93.5 \%$ of the total PSE in 2004 to $92.4 \%$ in 2005 , thanks to changes in rice policy in 2005, which included the abolition of government purchasing and the introduction of direct income support mechanisms. ${ }^{27}$

33. Given the need for structural reform in agriculture, government policy is focused on supporting larger and more efficient farms, for example, by targeting benefits on full-time farmers. In addition, the government is providing financial incentives to purchase farmland in order to boost the average farm size, which is only 1.3 hectare. The 2003 ten-year blueprint for developing farming aims at gradually reducing direct price support and introducing or expanding "green box" measures. ${ }^{28}$ It plans to raise public investment and loans to 119 trillion won (15\% of 2005 GDP) between 2004 and 2013 to boost rural income and compensate for reduced protection. About half is to be spent to enhance the competitiveness of agricultural products, with $27 \%$ to boost farmers' income through expanding the direct payment system and $15 \%$ to support regional development to boost rural farm and non-farm income. It is important to carefully monitor such spending to ensure its efficient use. A similar fund established in Japan to help agriculture adjust to the Uruguay Round resulted in inefficient public investment (Keizai Doyukai, 1997). In addition, the "FTA Facilitation Support Fund" was established in 2004 to alleviate any negative impact of the Korea-Chile FTA on the agricultural sector, with total expenditure of 1.2 trillion won planned between 2004 and 2010. The Fund will provide direct income payments and subsidise farmers engaged in grape and kiwi farming, which are directly affected by tariff elimination, to shift to new commodities. However, given the large number of FTAs envisaged in the near future, the Fund needs to be incorporated into an overall plan to develop the agricultural sector rather than an ad hoc response to each new trade agreement.

34. The "Trade Adjustment Act" in 2006 created a fund to support both workers and companies in manufacturing and manufacturing-related services that are negatively affected by FTAs. For individual workers, the fund provides job information, training services, consulting services and an employment subsidy. Firms are given management consulting services and financial support for R\&D, training and facility investment. Total expenditure is expected to reach 2.8 trillion won ( $0.3 \%$ of GDP) over the decade from 2007. Furthermore, the "SME Restructuring Facilitation Act" was created to support SMEs that intend to change their business activities as a result of FTAs. However, subsidies should be strictly linked to the impact of FTAs and focused on providing information and training in order to avoid creating moral hazard. Moreover, the coverage should be extended to more service industries.

2003-05 period. As agriculture accounts for $9 \%$ of employment, labour productivity in agriculture is about one-third of the national average, reflecting the small scale of farming and a lack of capital investment.

27. The impact of the revised policy on reducing the share of market price supports was partly offset by the appreciation of the exchange rate, which expanded the difference between the border price and the domestic price, and the fact that the direct payment system was not fully implemented in 2005 .

28. Green box measures include public stockbuilding for food security purposes, decoupled income support and structural adjustment assistance provided through producer retirement programmes. 
Figure 7. An international comparison of agricultural support during 2003-05

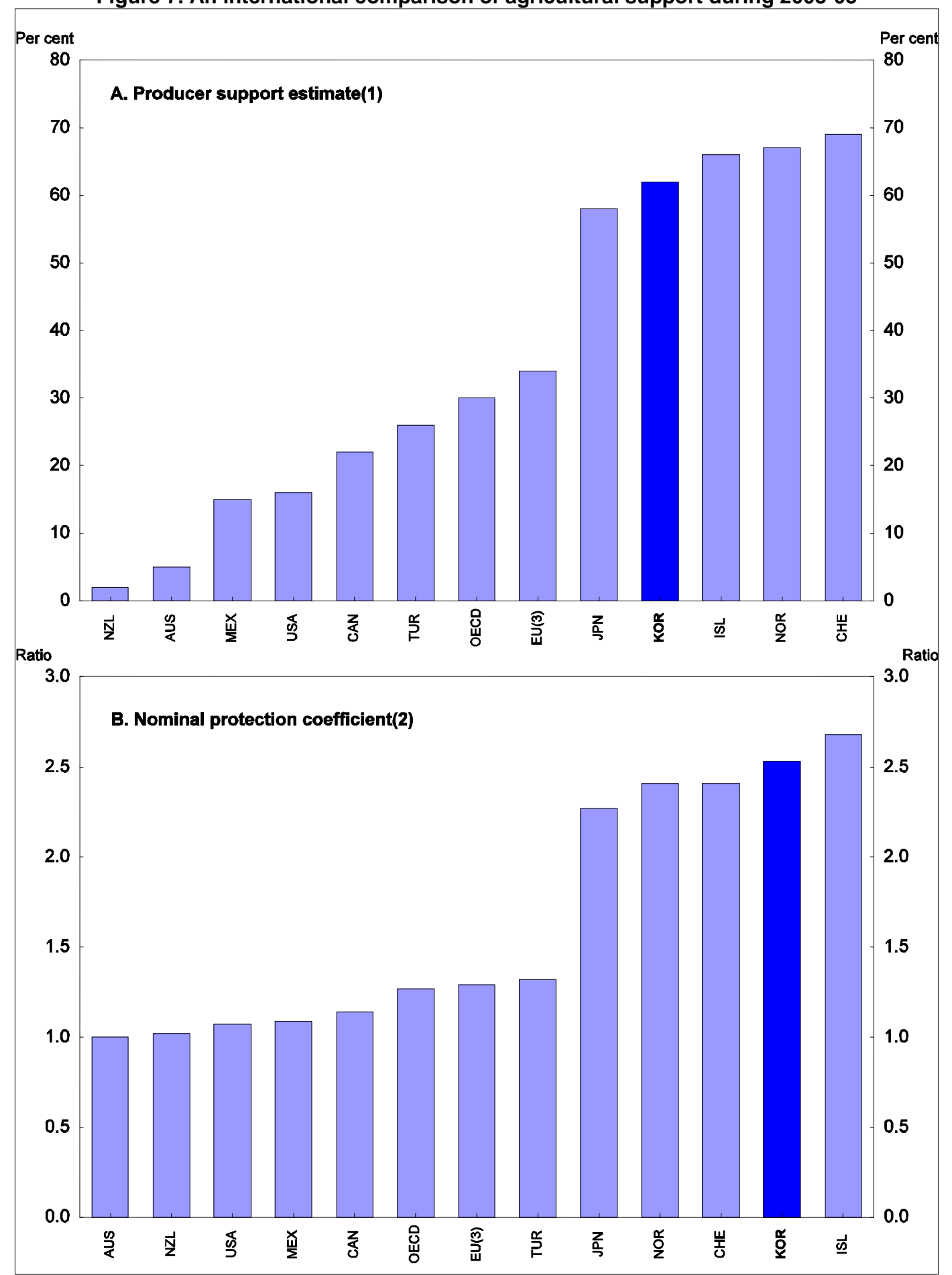

1. The producer support estimate is an indicator of the value of monetary transfers to agriculture resulting from agricultural policies. It is presented as a share of the total value of production at domestic producer prices.

2. The nominal protection coefficient is a measure of market protection defined as the ratio between the average prices paid by consumers and the international price.

3. EU15 for 2003 and EU25 from 2004.

Source: OECD (2006a), Agricultural Policies in OECD Countries: At a glance, OECD, Paris. 


\section{Liberalising the inflow of human resources}

35. Inflows of foreign workers to Korea's homogeneous society have been small, despite labour shortages in some sectors. In 2002, there were only 33900 foreign residents with employment permits (Table 9) - high-skilled professionals such as ICT technicians, researchers and university professors, and low-skilled workers (trainees who had spent one year in Korea) - in a labour force of 23 million. The extensive regularisation of workers without permits temporarily lifted the number of registered foreign workers to around 200000 in 2003. This was followed by the introduction of the Employment Permit System (see below), Nevertheless, at $0.8 \%$ of the labour force in 2004, the proportion of registered foreign workers was the fourth lowest in the OECD (Figure 1).

36. Increasing the number of foreign workers would have a significantly positive impact, particularly in the context of rapid population ageing and labour shortages. However, given the magnitude of the projected decline in the working-age population (Jones, 2008), inflows of foreign labour are not capable of fully offsetting demographic changes. Increased immigration should thus be accompanied by measures to raise labour force participation and remove constraints that limit the number of children.

\section{Policies to encourage inflows of low-skilled workers}

37. In 1993, the "Industrial Trainee System" (ITS) was introduced in response to the chronic shortage of labour in SMEs and the growing number of unregistered foreign workers, who suffered from the infringement of their rights. Under this system, SMEs in manufacturing, construction, fishery and agriculture could employ foreign workers for up to three years, one year as a trainee and two years as an employee, subject to an annual ceiling set by the government. The number of industrial trainees peaked at almost 60000 in 2000 (Table 9). However, the system has been criticised on the grounds that trainees were not protected by labour laws even though they were really workers and many left their training posts for jobs. Furthermore, there were a number of scandals involving the selection and entry of the trainees.

38. Responding to these problems, the government implemented the "Employment Permit System" (EPS) for unskilled workers in 2004 and decided to abolish the ITS in 2007. Under the EPS, foreign workers are provided employment permits for up to three years and are eligible for the same social insurance benefits and labour rights as domestic workers. However, they are not allowed to bring their families to Korea. The Foreign Workforce Policy Committee in the prime minister's office determines the inflows of low-skilled foreign workers, including the ceiling on the total number, industry of employment and countries of origin. Firms that wish to hire foreign workers must show that they have made efforts to hire domestic workers. The number of unregistered workers $-80 \%$ of the total in 2002 - declined in 2003 as a significant number were regularised. In addition, there is a special programme since 2002 for overseas Koreans who wish to work in Korea, including in jobs in the service and construction sectors, which are substantially closed to foreign workers. While the ITS was abolished, a trainee programme remains in place for Korean firms investing overseas, allowing them to train foreigners from the host country for two years in Korea (Table 9). 
ECO/WKP(2008)22

Table 9. Foreign workers in Korea

Thousand persons

\begin{tabular}{|c|c|c|c|c|c|c|c|c|c|c|c|c|c|}
\hline \multirow{3}{*}{ Year $^{1}$} & \multirow{3}{*}{ Total } & \multirow{3}{*}{$\begin{array}{l}\text { Per cent } \\
\text { of total } \\
\text { labour } \\
\text { force }\end{array}$} & \multicolumn{5}{|c|}{ Employment permit holders } & \multicolumn{4}{|c|}{ Trainee visa holders } & \multicolumn{2}{|c|}{ Unregistered workers } \\
\hline & & & \multicolumn{2}{|c|}{ High-skilled workers ${ }^{2}$} & \multicolumn{2}{|c|}{ Low-skilled workers } & \multirow{2}{*}{$\begin{array}{l}\text { Subtotal } \\
\text { Number }\end{array}$} & \multirow{2}{*}{$\begin{array}{l}\text { Industrial } \\
\text { trainees } \\
\text { Number }\end{array}$} & \multirow{2}{*}{$\begin{array}{c}\text { Trainees in firms } \\
\text { investing overseas } \\
\text { Number }\end{array}$} & \multicolumn{2}{|c|}{ Subtotal } & \multirow[b]{2}{*}{ Number } & \multirow[b]{2}{*}{ Per cent ${ }^{3}$} \\
\hline & & & Number & Per cent ${ }^{3}$ & Number & Per cent ${ }^{3}$ & & & & Number & Per cent ${ }^{3}$ & & \\
\hline 1995 & 128.9 & 0.6 & 8.2 & 6.4 & 0 & 0 & 8.2 & 23.6 & 15.2 & 38.8 & 30.1 & 81.9 & 63.5 \\
\hline 1996 & 210.5 & 1.0 & 13.4 & 6.4 & 0 & 0 & 13.4 & 38.3 & 29.7 & 68.0 & 32.3 & 129.1 & 61.3 \\
\hline 1997 & 245.4 & 1.1 & 15.9 & 6.5 & 0 & 0 & 15.9 & 48.8 & 32.7 & 81.5 & 33.2 & 148.1 & 60.4 \\
\hline 1998 & 157.7 & 0.7 & 11.1 & 7.0 & 0 & 0 & 11.1 & 31.1 & 15.9 & 47.0 & 29.8 & 99.5 & 63.1 \\
\hline 1999 & 219.2 & 1.0 & 14.4 & 6.6 & 0 & 0 & 14.4 & 49.5 & 20.0 & 69.5 & 31.7 & 135.3 & 61.7 \\
\hline 2000 & 285.4 & 1.3 & 17.0 & 6.0 & 2.1 & 0.7 & 19.1 & 59.0 & 18.5 & 77.5 & 27.2 & 189.0 & 66.1 \\
\hline 2001 & 329.6 & 1.5 & 19.6 & 6.0 & 8.1 & 2.4 & 27.6 & 33.2 & 13.5 & 46.7 & 14.1 & 255.2 & 77.5 \\
\hline 2002 & 362.8 & 1.6 & 21.5 & 5.9 & 12.3 & 3.4 & 33.9 & 25.6 & 14.0 & 39.7 & 11.0 & 289.2 & 79.7 \\
\hline 2003 & 395.8 & 1.7 & 20.1 & 5.1 & 187.0 & 47.2 & 207.0 & 38.9 & 11.8 & 50.7 & 12.8 & 138.1 & 34.9 \\
\hline 2004 & 421.7 & 1.8 & 20.4 & 4.8 & 176. & 41.8 & 196.6 & 28.1 & 8.4 & 36.6 & 8.7 & 188.5 & 44.7 \\
\hline 2005 & 347.6 & 1.4 & 23.4 & 6.7 & 105.1 & 30.2 & 128.5 & 32.2 & 6.1 & 38.3 & 11.1 & 180.8 & 52.0 \\
\hline 2006 & 424.8 & 1.8 & 27.3 & 6.4 & 166.6 & 39.2 & 193.9 & 38.2 & 5.8 & 44.0 & 10.4 & 186.9 & 44.0 \\
\hline
\end{tabular}

2. High-skilled workers include those with visa type from E-1 to E-7 such as researchers, professors and IT technicians.

3. Per cent of foreign labour force.

Source: Ministry of Justice. 
39. The impact of foreign workers on domestic economies is generally positive in the experience of OECD countries. In Korea, much of the benefit goes to SMEs in the manufacturing sector, which hires foreign workers willing to work at low wages that are unattractive to most Koreans. According to a recent survey of firms with foreign workers, more than half replied that increasing foreign employees is a short and long-term solution to labour shortages, suggesting a large demand for foreign workers (Yoo et al., 2004). However, given rapid structural change in Korea, in part as a result of globalisation, and the sharp decline in the labour force projected to start in 2016, keeping traditional labour-intensive industries alive through inflows of foreign workers is not a realistic option. Nevertheless, greater use of foreign labour can help ease the transition. Moreover, the EPS needs to be used to decrease the high share of unregistered workers in the foreign labour force. After falling significantly in 2003, the number of unregistered workers rebounded to more than half of foreign workers in Korea in 2005. There is thus a need to increase the number of employment permits and extend the permitted length of stay to meet the growing demand for foreign workers.

40. Other reforms are needed in the system of allowing low-skilled foreign workers in Korea. First, workers under the EPS should be able to work in the service sector, as is the case for overseas Koreans. For example, foreign workers could help fill shortages for carrying for the elderly, which is likely to increase in the context of population ageing. Second, the Ministries of Justice and Labour are jointly responsible for the EPS and the programme for overseas Koreans, in consultation with other ministries, while the Ministry of Justice directs the trainee program for firms investing overseas. The immigration control system, which involves more than a dozen ministries, needs to be streamlined.

\section{Raising the share of high-skilled workers}

41. Compared to unskilled workers, the immigration system gives preferential treatment to highskilled foreign workers. For example, there is no ceiling on the total number of visas, visas can be renewed an unlimited number of times and foreign workers are allowed to change employers or work in another field. In 2000, the system was reformed to encourage the entry of specialists in high-technology sectors such as ICT, e-commerce and e-business. ${ }^{29}$ Despite the preferential treatment and government efforts to attract such workers, the number of foreign high-skilled workers in Korea has stagnated at around 25000 since 2000, accounting for about $6 \%$ of the total foreign labour force. In contrast, skilled labour accounts for $19 \%$ of foreign labour in Japan. The low share of high-skilled workers is largely a result of problems in the business and living environment and administrative regulations that make it difficult to work in Korea. According to a survey of employers, more than half of those currently employing foreign high-skilled workers identified the administrative regulations controlling their entry and stay as the most serious obstacle (Lee et al., 2005). As Korea endeavours to develop itself into a knowledge-based economy, the importance of attracting high-quality foreign workers is increasing. It is essential, therefore, to further improve the immigration control system for such workers to facilitate their entry to Korea.

\section{Conclusion}

42. Korea's geographical location, well developed infrastructure, high-quality labour force and the growing purchasing power of its consumers will help it achieve its goal of becoming a regional hub for northeast Asia. However, taking advantage of these qualities requires a national consensus about the gains from globalisation in order to foster a more open environment. It is thus important to change the negative perception of globalisation. Greater openness would result in lower prices for consumers and higher returns for shareholders. It is particularly important to encourage a more open stance in services, which is relatively more closed to international competition and characterised by a low level of productivity relative

29. Major measures included issuing plural visas, extending the maximum length of stay from two to three years and expanding the range of domestic activities. 
to manufacturing. Opening up the service sector, including social services, would increase overall efficiency and productivity, making this sector an engine for growth. Given the links between foreign investment, trade and inflows of foreign workers, it is important to pursue a comprehensive approach that would allow FDI inflows, imports and the number of foreign workers to increase from their current low levels, compared to other OECD countries. For example, a comprehensive FTA that includes services would encourage FDI inflows in Korea. Specific recommendations are presented in Box 4.

\section{Box 4. Summary of recommendations to increase the integration of Korea in the world economy}

\section{Removing obstacles to the inflows of foreign investment}

- Foster a foreign investment-friendly environment by providing clear evidence of the gains from such investment.

- $\quad$ Develop the $M \& A$ market, including cross-border M\&A, by relaxing related regulations and easing negative public sentiment, while avoiding steps to protect domestic firms from cross-border M\&As.

- $\quad$ Further liberalise FDI restrictions, in particular by reducing or removing foreign ownership ceilings in sectors such as telecommunications, transport and electricity.

- $\quad$ Reduce product market regulation, especially in services, to encourage domestic and foreign investment, and phase out the regulations on construction in the capital region.

- Increase the predictability of the business environment by enhancing the transparency of tax and financial supervisory policies and removing the scope for discretionary interpretation, application and enforcement.

- Resolve the issues in the labour market, including labour-management relations, which discourage FDI.

- Extend the regulatory reforms introduced in the Free Economic Zones to improve the business and living conditions to other parts of the country and ensure a level playing field between domestic and foreign firms.

- Streamline the various zones created to encourage FDI and provide equal treatment of manufacturing and service sectors.

- Increase transparency by limiting the scope of special incentives, such as cash grants, for foreign firms.

- $\quad$ Avoid preferential fiscal and regulatory treatment, which distorts the locational decisions of foreign investors.

- Do not allow the emphasis on special zones to distract the authorities from the fundamental objective of improving the business climate, which would promote domestic, as well as international, investment.

- Review special zone schemes regularly to ensure that the economic benefits exceed the costs, while minimising the deadweight and opportunity cost of such zones.

Improving the climate for international trade

- $\quad$ Pursue the liberalisation of trade barriers through multilateral trade negotiations to further reduce the level of trade restrictions, including tariff and non-tariff barriers.

- Further harmonise Korean regulations and standards with international standards to reduce barriers to imports. 
- $\quad$ Pursue WTO-consistent regional free trade agreements, covering substantially all products.

- $\quad$ Strengthen market principles in the agricultural sector, in part by reducing market price supports, thereby benefiting consumers and broadening the scope for regional free trade agreements.

- $\quad$ Limit moral hazard in policies used to support industries and workers negatively affected by free trade agreements by applying strict causality tests and focusing support on providing information and training.

\section{Promoting the inflows of human resources}

- $\quad$ Reform the Employment Permit System (EPS) to reduce the number of unregistered workers and allow a sufficient number of low-skilled foreign workers to ease labour shortages in some sectors.

- Allow low-skilled foreign workers to be employed in the service sector, in addition to manufacturing.

- Increase the inflow of high-skilled workers by improving the immigration control system, as well as the business and living environment. 


\section{BIBLIOGRAPHY}

Bora, Bijit, Aki Kuwahara and Sam Laird (2002), "Quantification of Non-tariff Measures", United Nations Conference on Trade and Development (UNCTAD) Study Series No. 18, New York and Geneva.

Conway, Paul, Veronique Janod, and Giuseppe Nicoletti (2005), "Product Market Regulation in OECD Countries: 1998 to 2003”, OECD Economics Department Working Paper No. 419, OECD, Paris.

Golub, Steve (2003), "Measures of Restrictions on Inward Foreign Direct Investment for OECD Countries", OECD Economic Studies No. 36, OECD, Paris.

Golub, Stephen and Takeshi Koyama (2006), “OECD's FDI regulatory restrictiveness index: revision and extension to more economies", OECD Economics Department Working Paper No. 525, OECD, Paris.

Hong, Jonghak, Moonhyun Song and Pyungryang Wi (2006), "International comparison of the total ceiling on shareholding and corporate governance of large business groups", Presentation for "Symposium on improving corporate governance of large business group in line with global standards", Seoul (in Korean).

Huh, Jaejun and Sunchan Park (2006), "Impact of a Korea-US FTA on the Korean labour market", Korea Labour Institute Research Paper, Seoul (in Korean).

Invest Korea (2006), 2006 survey on obstacles in the business environment for foreign firms, Seoul (in Korean).

Jang, Hasung (2006), "Corporate Governance Reform and Corporate Competitiveness in Korea", International Symposium on Reform of Corporate Governance, Seoul (in Korean).

Jones, Randall S. (2008), "Public Social Spending in the Context of Rapid Population Ageing", OECD Economics Department Working Paper, forthcoming, OECD, Paris.

Jones, Randall S. and Tadashi Yokoyama (2008), "Reforming Housing and Regional Policies in Korea", OECD Economics Department Working Paper, forthcoming, OECD, Paris.

Kang, Moonsung et al. (2004), “Assessment and tasks for an FTA with large economic blocs”, Korea Institute for International Economic Policy Research Paper, Seoul (in Korean).

Keizai Doyukai (1997), "This is how we change Japan: Concrete measures to reform the mechanism of the Japanese economy", Tokyo (in Japanese).

KIEP (Korea Institute for International Economic Policy) (2006), The need for a Korea-US FTA and its economic impact, Seoul (in Korean).

Kim, Hyunwook (2005), "Understanding and regulation of increasing foreign capital in the banking sector", Korea Development Institute Research Paper 2005-07, Seoul (in Korean). 
Kim, Joon-Kyung, Yangseon Kim and Chung H. Lee (2006), "Trade, Investment and Economic Interdependency between South Korea and China", Korea Development Institute and East-West Center, University of Hawaii.

Korea Trade Investment Promotion Agency (2006), Analysis of rising Korean exports to China, Seoul (in Korean).

Lee, Kyuyong et al. (2005), "Analysis of the labour market for high-skilled foreign workers", Korea Labour Institute Research Paper 2005-10, Seoul (in Korean).

LG Economic Research Institute (2006), "Korea-US FTA and the current competitiveness of the service industry in Korea" Research Paper, Seoul (in Korean).

Ministry of Commerce, Industry and Energy (2005), "2004 survey on the management of foreign-invested firms", Seoul (in Korean).

Nam, Kwanghee and Seonghoon Yoon (2006), "Korea's FDI policy: problems and tasks for improvement", Bank of Korea Research Paper, Seoul (in Korean).

Nicoletti, Giuseppe, Steve Golub, Dana Hajkova, Daniel Mirza and Kwang Yeol Yoo (2003), “The Influence of Policies on Trade and Foreign Direct Investment", OECD Economic Studies No. 36, OECD, Paris.

Oh, Hoil and Changheyun Park (2006), "Expansion of global M\&As and its implication”, Bank of Korea research paper, Seoul (in Korean).

OECD (2003), Checklist for Foreign Direct Investment Incentive Policies, www.oecd.org/dataoecd/45/21/2506900.pdf, OECD, Paris.

OECD (2005a), "The benefits of liberalising product markets and reducing barriers to international trade and investment in the OECD”, OECD Economics Department Working Paper No. 463, OECD, Paris.

OECD (2005b), International Investment Perspectives, OECD, Paris.

OECD (2005c), OECD Economic Globalisation Indicators, OECD, Paris.

OECD (2005d), OECD Economic Survey of Korea, OECD, Paris.

OECD (2006a), Agricultural Policies in OECD Countries: At a Glance, OECD, Paris.

OECD (2006b), International Migration Outlook, OECD, Paris.

OECD (2006c), OECD Economic Survey of Japan, OECD, Paris.

OECD (2006d), Policy Framework for Investment, OECD, Paris.

OECD (2007a), Korea: Progress in implementing regulatory reform, OECD Reviews of Regulatory Reform, OECD, Paris.

OECD (2007b), OECD Economic Survey of Korea, OECD, Paris. 
Park, Kyungseo (2005), "Assessment of transparency and equity of markets and corporations", Korea Corporate Governance Service, Seoul (in Korean).

UNCTAD (United Nations Conference on Trade and Development) (2006), World Investment Report 2006, UNCTAD, New York and Geneva.

WTO (World Trade Organization) (2004), Trade Policy Reviews (for Korea, Japan, United States and European Communities), Geneva.

Yoo, Kilsang et al., (2004), “Analysis of the labour market for low-skilled foreign workers”, Korea Labour Institute Research Paper 2004-14, Seoul (in Korean).

Yoo, Kilsang, Junghye Lee and Kyuyong Lee (2004), "International comparison of foreign labour markets", Korea Labour Institute Research Paper, Seoul (in Korean). 


\section{WORKING PAPERS}

The full series of Economics Department Working Papers can be consulted at www.oecd.org/eco/Working_Papers/

613. Reforming housing and regional policies in Korea

(May 2008) Randall S. Jones and Tadashi Yokoyama

612. Moving towards more sustainable healthcare financing in Germany

(May 2008) N. Brandt

611. Improving education outcomes in Germany

(May 2008) David Carey

610. Have developed countries escaped the curse of distance?

(May 2008) Hervé Boulhol and Alain de Serres

609. Measures of international transport cost for OECD countries $\backslash$

(April 2008) Stephen S. Golub and Brian Tomasik

608. Encouraging labour force participation in Chile

(April 2008) D. Contreras, L. de Mello and E. Puentes

607. Tackling business and labour informality in Chile

(April 2008) D. Contreras, L. de Mello and E. Puentes

606. Delivery cost-efficient public services in health care, education and housing in Chile (April 2008) D. Contreras, L. de Mello and E. Puentes

605. Managing Chile's macroeconomy during and after the copper price boom (April 2008) Luiz de Mello

604. Avoiding the value added tax: Theory and cross-country evidence (April 2008) Luiz de Mello

603. Oil Price Shocks, Rigidities and the Conduct of Monetary Policy: Some Lessons from a New Keynesian Perspective

(April 2008) Romain Duval and Lukas Vogel

602. The Contribution of Economic Geography to GDP Per Capita (April 2008) Hervé Boulhol, Alain de Serres and Margit Molnar

601. Estimating a supply block for Poland

(April 2008) Rafal Kierzenkowski, Patric Ollivaud, Franck Sédillot and Philippe Briard

600. Product market regulation and economic performance across Indian states

(March 2008) Paul Conway, Richard Herd and Thomas Chalaux

599. Improving product market regulation in India: an international and cross-state comparison (March 2008) Paul Conway and Richard Herd 
598. Revenue buoyancy and its fiscal policy implications (February 2008) Isabelle Joumard and Christophe André

597. Monetary policy, market excesses and financial turmoil (February 2008) Rudiger Ahrend, Boris Cournède and Robert Price

596. Explaining differences in hours worked among OECD countries: an empirical analysis (February 2008) Sven Blondal and Jean-Marc Burniaux

595. Fiscal policy in India: past reforms and future challenges (February 2008) Richard Herd and Willi Leibfritz

594. The significance of Switzerland's enormous current-account surplus (March 2008) Peter Jarrett and Céline Letremy

593. Interdependencies between monetary policy and foreign-exchange intervention under inflation targeting: the case of Brazil and the Czech Republic (January 2008) Jean-Yves Gnabo, Luiz de Mello and Diego Moccero

592. Solow or Lucas? Testing growth models using panel data from OECD countries (December 2007) Jens Arnold, Andrea Bassanini and Stefano Scarpetta

591. The private internal rates of return to tertiary education: new estimates for 21 OECD countries (December 2007) Romina Boarini and Hubert Strauss.

590. Making federalism work (December 2007) Alexandra Bibbee

589. The wage premium on tertiary education: New estimates for 21 OECD countries (December 2007) Hubert Strauss and Christine de la Maisonneuve

588. Enhancing the benefits of financial liberalisation (March 2007) Stefan Ide, Jens Høj and Patrick Lenain

587. Improving incentives in tertiary education (March 2007) Jens Høj

586. Globalisation and the European Union: which countries are best placed to cope? (December 2007) David Rae and Marte Sollie

585. Primary and secondary education in the United States (November 2007) Peter Tulip and Gregory Wurzburg

584. Financing higher education in the United States (November 2007) Peter Tulip

583. Corporate net lending: a review of recent trends (November 2007) Christophe André, Stéphanie Guichard, Mike Kennedy and David Turner

581. Local government finances: The link between intergovernmental transfers and net worth (September 2007) Luiz de Mello 